Article

\title{
A Comparison of Uric Acid Optical Detection Using as Sensitive Materials an Amino-Substituted Porphyrin and Its Nanomaterials with CuNPs, PtNPs and Pt@CuNPs
}

\author{
Camelia Epuran ${ }^{1}$, Ion Fratilescu ${ }^{1}$, Diana Anghel ${ }^{1}$, Mihaela Birdeanu ${ }^{2}$, Corina Orha ${ }^{2}$ \\ and Eugenia Fagadar-Cosma ${ }^{1, *(\mathbb{D})}$
}

1 Institute of Chemistry "Coriolan Dragulescu”, Mihai Viteazu Ave. 24, 300223 Timisoara, Romania; ecamelia@acad-icht.tm.edu.ro (C.E.); ionfratilescu@acad-icht.tm.edu.ro (I.F.); danghel@acad-icht.tm.edu.ro (D.A.)

2 National Institute for Research and Development in Electrochemistry and Condensed Matter, Plautius Andronescu Street 1, 300224 Timisoara, Romania; mihaione2002@yahoo.com (M.B.); orha.corina@gmail.com (C.O.)

* Correspondence: efagadar@yahoo.com or efagadarcosma@acad-icht.tm.edu.ro

check for updates

Citation: Epuran, C.; Fratilescu, I.; Anghel, D.; Birdeanu, M.; Orha, C.; Fagadar-Cosma, E. A Comparison of Uric Acid Optical Detection Using as Sensitive Materials an AminoSubstituted Porphyrin and Its Nanomaterials with CuNPs, PtNPs and Pt@CuNPs. Processes 2021, 9 , 2072. https://doi.org/10.3390/ pr9112072

Academic Editors: Yanbo Pan, Zhenmeng Peng, Chunhai Yi and Xiaochen Shen

Received: 17 September 2021 Accepted: 17 November 2021 Published: 19 November 2021

Publisher's Note: MDPI stays neutral with regard to jurisdictional claims in published maps and institutional affiliations.

Copyright: (c) 2021 by the authors. Licensee MDPI, Basel, Switzerland. This article is an open access article distributed under the terms and conditions of the Creative Commons Attribution (CC BY) license (https:// creativecommons.org/licenses/by/ $4.0 /)$.

\begin{abstract}
Hybrid nanomaterials consisting in 5,10,15,20-tetrakis(4-amino-phenyl)-porphyrin (TAmPP) and copper nanoparticles (CuNPs), platinum nanoparticles (PtNPs), or both types (Pt@CuNPs) were obtained and tested for their capacity to optically detect uric acid from solutions. The introduction of diverse metal nanoparticles into the hybrid material proved their capacity to improve the detection range. The detection was monitored by using UV-Vis spectrophotometry, and differences between morphology of the materials were performed using atomic force microscopy (AFM). The hybrid material formed between porphyrin and PtNPs hasthe best and most stable response for uric acid detection in the range of $6.1958 \times 10^{-6}-1.5763 \times 10^{-5} \mathrm{M}$, even in the presence of very high concentrations of the interference species present in human environment.
\end{abstract}

Keywords: uric acid detection; PtNPs; CuNPs; Pt@CuNPs; amino-substituted porphyrin; hybrid porphyrin nanomaterials; UV-vis spectroscopy; AFM

\section{Introduction}

Uric acid (UA), with IUPAC nomenclature: 7,9-dihydro- $1 H$-purine-2,6,8(3H)-trione, is formed in human body by thecatabolization of the purine nucleosides [1] that are also components of normal DNA.

In healthy people, normal levels of UA vary function of the nature of analyzed samples between 0.13 and $0.46 \mathrm{mM}$ in serum, ten times higher $1.49-4.50 \mathrm{mM}$ in urine, and in the range from $120 \mu \mathrm{M}$ to $400 \mu \mathrm{M}$ in the saliva [2,3].

Higher levels, above $420 \mu \mathrm{M}$ in serum and $4.43 \mathrm{mM}$ in urine, leading to hyperuricemia, are characteristics of diseases such as: hypertension, cardiovascular disease, gout, arthrophlogosis, and chronic nephropathy. They can also represent a risk factor for 2-type diabetes [4,5]. On the other hand, having uric acid in serum and urine lower than $120 \mu \mathrm{M}$ and, respectively, $1.48 \mathrm{mM}$ may cause neurodegenerative diseases, potentially leading to Wilson's disease due to copper toxicity and worsening multiple sclerosis or oxidative stress [6].

In consequence, UA is considered to be an important biomarker in urine, serum, and saliva, and monitoring for high uric acid levels is a demand when people are undergoing radiation or chemotherapyin cases of obesity, psoriasis, or hypothyroidism [7]. Different techniques for UA detection were successfully used in the last period. The selection of methods is made by comparing their main performances (namely, detection domain, limit of detections, and major advantages/drawbacks (Table 1)). 
Nanoparticles such as copper, gold, $\mathrm{CeO}_{2}$, or magnetite nanoparticles (e.g., CuNPs, AuNPs, $\mathrm{CeO}_{2} \mathrm{NPs}_{2} \mathrm{Fe}_{3} \mathrm{O}_{4} \mathrm{NPs}$ ) or hybrid materials containing them, based on polymers, graphene or mesoporous silica spheres, were used as sensitive materials for the selective detection of UA by electrochemical [8,9], spectrophotometric (limit of detection $5 \mu \mathrm{M}$ ) [10,11], chemiluminescent [12], or by HPLC methods [13].

Modified glassy carbon electrodes (GCE) with citric acid were used for the detection of uric acid and exhibited a good linear response in the range of $7.5 \mu \mathrm{M}-0.18 \mathrm{mM}$ [8]. UA was determined from human urine on copper(II)-polydopamine immobilized on GCE surface by differential pulse voltammetry. The linear response in the range of $0.06-1.68 \mathrm{mM}$ was possible only in the absence of ascorbic acid (AA) interference [9]. The simultaneous determination of AA (limit of detection $1.65 \mu \mathrm{M}$ ) and UA (limit of detection $2.14 \mu \mathrm{M}$ ) in human blood serumwas reported by electrocatalytic oxidation using modified glassy carbonelectrodes (GCE) with a composite film of AuNPs and mesoporous silica spheres [14].

By performing HPLC separations on a reversed-phase C18 column, with UV detection at $205 \mathrm{~nm}$, it was possible to realize simultaneous determination of creatinine and UA in human urine samples [13].

UA could quench the fluorescence of sensitive fluorophores through coordination, $\pi-\pi$ hydrophobic interactions, or even hydrogen bonding. The fluorescence quenching of gold nanoclusters in the presence of iodide was reported to detect UA in the concentrations range of $0.7-80 \mu \mathrm{M}$, with a detection limit of $120 \mathrm{nM}$, from blood samples [15,16].

Using UV-Vis spectrometry, different concentrations $(0.8 \mathrm{mg} / \mathrm{mL}, 0.6 \mathrm{mg} / \mathrm{mL}$, $0.4 \mathrm{mg} / \mathrm{mL}$ ) of uric acid were precisely detected at a constant absorption UV wavelength, $294.46 \mathrm{~nm}$ in a short time response [17,18]. A colorimetric assay using Pt@Agnanoflowers (Pt@AgNFs) was developed to detect UA with high sensitivity [19]. The color of the solution changes from colorless to blue, depending on the amount of UA.

Due to their versatile photo-sensitive properties, porphyrins can act both as recognition or detection units in bioanalysis [20]. The synergistic effect between 5,10,15,20-tetra (4-pyridyl)-21H, 23H-porphyrin and graphene oxide was exploited to realize an UA amperometric biosensor having linear range from 0.02 to $5 \mu \mathrm{M}$ and a detection limit of $1 \mu \mathrm{M}$, capable to function both in urine and blood samples [21].

The purpose of this study was to develop improved nanomaterials based on synergistic behavior of a symmetrical amino-substituted porphyrin (namely 5,10,15,20-tetrakis(4amino-phenyl)-porphyrin, (TAmPP), in association with CuNPs, PtNPs, or Pt@CuNPs) and to select the best performing sensitive material for fast, sensitive, and selective uric acid optical detection. For enabling the selections, comparative testing was performed using porphyrin alone and its complex nanomaterials with CuNPs, PtNPs, and platinum covered copper core nanoparticles (Pt@CuNPs). Structures of the amino-functionalized porphyrin and of the uric acid are provided in Figure 1.

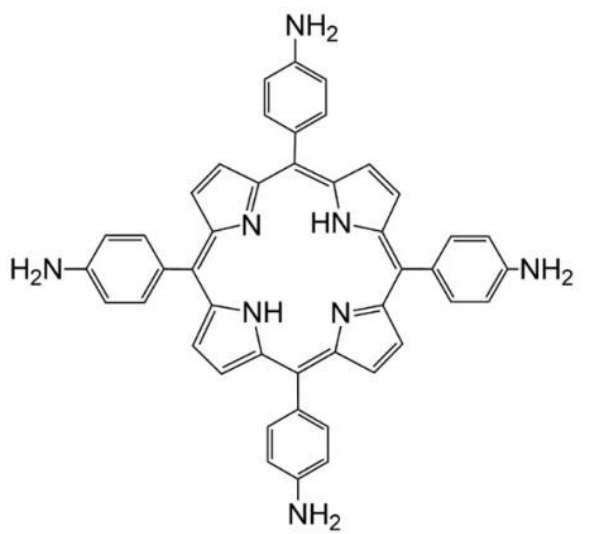<smiles>O=c1[nH]c(=O)c2[nH]c(=O)[nH]c2[nH]1</smiles>

Figure 1. The Structure of 5,10,15,20-tetrakis(4-amino-phenyl-)porphyrin, (TAmPP) and of uric acid (UA) in its lactam form. 
Table 1. Recently developed detection methods of uric acid. Sensitive materials, concentration ranges, and detection limits.

\begin{tabular}{|c|c|c|c|c|c|}
\hline Sensitive Material & Method of Detection & Detection Range & Limit of Detection & Advantages/Disadvantages & Ref \\
\hline $\begin{array}{l}\text { Porphyrin-graphene } \\
\text { oxide hybrid nanosheets } \\
\text { using as porphyrin } \\
5,10,15,20 \text {-Tetra } \\
\text { (4-pyridyl)-21H, } \\
\text { 23H-porphine }\end{array}$ & $\begin{array}{c}\text { Sensitive } \\
\text { Electrochemical } \\
\text { Detection }\end{array}$ & 20 to $5000 \mu \mathrm{M}$ & $1 \mu \mathrm{M}$ & $\begin{array}{c}\text { - wide linear range } \\
\text { - quick response } \\
\text { - low level of detecting } \\
\text { - excellent repeatability and stability; } \\
\text { - good biocompatibility } \\
\text { - high conductivity } \\
\text { - quick mass transport } \\
\text { - synergistic catalytic effect between } \\
\text { porphyrin and RGO }\end{array}$ & [21] \\
\hline $\begin{array}{c}\text { Flexible } \\
\text { microneedle electrode } \\
\text { array-based } \\
\text { biosensor and } \\
\text { multi-channel portable } \\
\text { electrochemical analyzer }\end{array}$ & $\begin{array}{l}\text { Electrochemical } \\
\text { method }\end{array}$ & 100 to $1200 \mu \mathrm{M}$ & $4 \mu \mathrm{M}$ & $\begin{array}{c}\text { - simultaneous detection of multiple } \\
\text { analytes } \\
\text { - excellent sensing capabilities to } \\
\text { these analytes } \\
\text { - high sensitivity } \\
\text { - linear ranges covering the } \\
\text { concentration } \\
\text { for clinical diagnosis } \\
\text {-small size, low cost }\end{array}$ & [18] \\
\hline $\begin{array}{c}\text { Mn(III)-5-(4-Amino- } \\
\text { phenyl)-10,15,20- } \\
\text { triphenyl- } \\
\text { porphyrin } \\
\text { Graphene modified GCE }\end{array}$ & $\begin{array}{l}\text { Electrochemical } \\
\text { methods: differential } \\
\text { pulse voltammetry and } \\
\text { amperometric } \\
\text { techniques }\end{array}$ & $\begin{array}{c}0.5 \text { to } 500 \mu \mathrm{M} \text { and } 20 \\
\text { to } 290 \mu \mathrm{M}\end{array}$ & $0.30 \mu \mathrm{M}$ and $1.74 \mu \mathrm{M}$ & $\begin{array}{c}\text {-excellent electrocatalytic } \\
\text { Activity } \\
\text { - good stability } \\
\text { - high selectivity towards UA } \\
\text {-low fabrication costs } \\
\text { - wide linear ranges } \\
\text { - low detection limit } \\
\text { - potential to use in the clinical } \\
\text { detection }\end{array}$ & [22] \\
\hline
\end{tabular}

\begin{tabular}{|c|c|c|c|c|c|}
\hline $\begin{array}{l}\text { Chloro [3,7,12,17-tetra- } \\
\text { methyl-8,13- } \\
\text { divinyl- } \\
\text { porphyrin- } \\
2,18- \\
\text { dipropanoato }(2-)] \\
\text { Fe(III)/multi-wall } \\
\text { carbon nanotubes }\end{array}$ & $\begin{array}{l}\text { Electrochemical } \\
\text { method }\end{array}$ & $5.80 \mu \mathrm{M}$ to $1.30 \mathrm{mM}$ & $0.30 \mu \mathrm{M}$ & $\begin{array}{c}\text { - low cost } \\
\text { - high selectivity and sensitivity }\end{array}$ & [23] \\
\hline $\begin{array}{l}\text { Cobalt tetra } \\
\text {-phenyl- } \\
\text { porphyrin with } \\
\text { chemically reduced } \\
\text { graphene oxide }\end{array}$ & $\begin{array}{l}\text { Electrochemical } \\
\text { method }\end{array}$ & 0.5 to $40 \mu \mathrm{M}$ & $0.15 \mu \mathrm{M}$ & $\begin{array}{l}\text { - good stability } \\
\text { - low detection limit }\end{array}$ & {$[24]$} \\
\hline $\begin{array}{c}\text { Pt@Ag } \\
\text { nanoflowers }\end{array}$ & $\begin{array}{l}\text { Spectro- } \\
\text { phtometric } \\
\text { detection }\end{array}$ & $0.5-150 \mu \mathrm{M}$ & $0.3 \mu \mathrm{M}$ & $\begin{array}{c}\text {-simple and } \\
\text { fast UA detection } \\
\text { platform for point-of-care diagnostics }\end{array}$ & [19] \\
\hline $\begin{array}{l}\text { Picolinic-Acid- } \\
\text { Functionalized } \\
\text { Metal-Organic } \\
\text { Frameworks }\end{array}$ & Fluorescence analysis & 0.01 to $400 \mu \mathrm{M}$ & $0.0023 \mu \mathrm{M}$ & $\begin{array}{l}\text {-short reaction time, high } \\
\text { selectivity, high sensitivity, and wide } \\
\text { linear range for UA detection }\end{array}$ & [3] \\
\hline $\begin{array}{l}\mathrm{Ru}(\mathrm{III})-2,2^{\prime}- \\
\text { bipyridine/tri- } n \text {-propyl- } \\
\text { amine }\end{array}$ & $\begin{array}{l}\text { Quenching of the elec- } \\
\text { trochemiluminescence }\end{array}$ & 1 to $75 \mu \mathrm{M}$ & $1 \mu \mathrm{M}$ & $\begin{array}{l}\text {-possible interfering biological } \\
\text { species, such as cysteine, oxalate, } \\
\text { purine, glucose, and urea. } \\
\text {-ascorbic acid causes interference }\end{array}$ & [25] \\
\hline $\begin{array}{l}\text { Nanohybrid } \\
\text { constructed of gold } \\
\text { nanoclusters (Au NCs) } \\
\text { and quantum dots }\end{array}$ & $\begin{array}{l}\text { fluorescence quenching } \\
\text { at } 685 \mathrm{~nm} \text { with the } \\
\text { addition of hydrogen } \\
\text { peroxide in the } \\
\text { presence of } \mathrm{Fe}^{2+} \text { ions }\end{array}$ & 0.67 to $60 \mu \mathrm{M}$ & $0.21 \mu \mathrm{mol} \cdot \mathrm{L}^{-1}$ & $\begin{array}{c}\text {-successfully applied in the } \\
\text { determination of uric acid in serum } \\
\text { samples. } \\
\text {-selectivity } \\
\text { over other molecules and proteins } \\
\text {-good detection limit and dynamic } \\
\text { range }\end{array}$ & [26] \\
\hline $\begin{array}{l}\text { 5,10,15,20-tetrakis }(4- \\
\text { amino-phenyl)- } \\
\text { porphyrin } \\
\text { (TAmPP) }\end{array}$ & $\begin{array}{l}\text { Spectro- } \\
\text { photometric } \\
\text { detection }\end{array}$ & 0.582 to $5.647 \mu \mathrm{M}$ & $0.28 \mu \mathrm{M}$ & -low detection limit & This work \\
\hline $\begin{array}{l}\text { (TAmPP) with copper } \\
\text { nanoparticles (CuNPs) }\end{array}$ & $\begin{array}{l}\text { Spectro- } \\
\text { photometric } \\
\text { detection }\end{array}$ & 5.003 to $14.01 \mu \mathrm{M}$ & $0.61 \mu \mathrm{M}$ & $\begin{array}{c}\text { - } \mathrm{CH}_{3} \mathrm{COONa} \text { and sodium salicylate } \\
\text { in high concentrations can induce } \\
\text { errors }\end{array}$ & This work \\
\hline $\begin{array}{l}\text { (TAmPP) with platinum } \\
\text { nanoparticles (PtNPs) }\end{array}$ & $\begin{array}{l}\text { Spectro- } \\
\text { photometric } \\
\text { detection }\end{array}$ & 6.196 to $15.763 \mu \mathrm{M}$ & $0.57 \mu \mathrm{M}$ & $\begin{array}{l}\text {-good and stable response for UA in } \\
\text { the presence of the most common } \\
\text { interference species in biological } \\
\text { fluids. } \\
\text {-wide range of detection }\end{array}$ & This work \\
\hline $\begin{array}{l}\text { (TAmPP) with } \\
\text { Pt@CuNPs }\end{array}$ & $\begin{array}{l}\text { Spectro- } \\
\text { photometric } \\
\text { detection }\end{array}$ & $1.68 \times$ to $8.08 \mu \mathrm{M}$ & $0.41 \mu \mathrm{M}$ & $\begin{array}{l}-\mathrm{CH}_{3} \mathrm{COONa} \text { and sodium salicylate } \\
\text { introduces small errors }\end{array}$ & This work \\
\hline
\end{tabular}




\section{Materials and Methods}

\subsection{Atomic Force Microscopy (AFM)}

AFM images were recorded in contact mode on a Nanosurf ${ }^{\circledR 囚}$ EasyScan 2 Advanced Research AFM, using a piezoelectric ceramic cantilever. The samples were deposited by drop-casting method on silica plates.

\subsection{UV-Vis Spectroscopy}

UV-vis spectra were performed on a device JASCO V-650 with quartz cuvettes of $1 \mathrm{~cm}$ path length. Each specific measurement regarding UA detection was performed three times. Standard deviation (SD) results were always lower than 0.0208 .

\subsection{X-ray Diffraction (XRD)}

X-ray diffraction (XRD) was carried outon a X'pert Pro MPD X-ray diffractometer, with monochromatic $\mathrm{Cu} \mathrm{K} \alpha(\lambda=1.5418 \AA)$ incident radiation.

\subsection{Emission-Scanning Electron Microscopy—(SEM)}

The measurements were taken using a field emission-scanning electron microscope (SEM/EDAX, Model IN-SPECT S), equipped with EDS detector, capable to detect signals for both backscattered electrons and secondary electrons, using low vacuum at a magnification $=3000 \times$, high voltage $=30.00 \mathrm{KV}$ and weight distance $=10.1 \mathrm{~mm}$.

\subsection{Reagents}

Dimethyl sulfoxide, $\mathrm{H}_{2} \mathrm{PtCl}_{6} \times 6 \mathrm{H}_{2} \mathrm{O}$ and trisodium citrate of highest purity were produced by Sigma-Aldrich (St. Louis, MO, USA). Copper(II) chloride dihydrate and sodium borohydride were provided by Merck (Darmstadt, Germany).

\subsection{Calculation of the Detection Limit}

The limit of detection $(L O D)$ was calculated using the formula:

$$
L O D=\left[3.3 \times\left(\frac{\sigma}{s}\right)\right]
$$

where the coefficients 3.3 is the expansion factor, obtained with a $95 \%$ confidence level; $s$ is the slope of the signal/concentration functional relationship; and $\sigma$ is standard deviation of response-Y intercept [27].

\subsection{Obtaining of 5,10,15,20-Tetrakis(4-amino-phenyl)porphyrin (TAmPP)}

The synthesis of 5,10,15,20-meso-tetrakis-(p-amino-phenyl)-porphyrin, was conducted in two steps, obtaining first the nitro-derivative, 10,15,20-meso-tetrakis- ( $p$-nitro-phenyl)porphyrin, starting from $p$-nitrobenzaldehyde and acetic anhydride vigorously stirred under nitrogen atmosphere in propionic acid as solvent followed by condensation reaction with equimolecular amount of pyrrole. The second step, consisting in reduction of nitrogroups to amino ones, was made under an argon atmosphere in concentrated $\mathrm{HCl}$, usingan excess of dihydrated $\mathrm{SnCl}_{2}$ [28].

\subsection{Synthesis of the Copper Colloid (CuNPs)}

Method for synthesis of $\mathrm{Cu}$ colloid was adapted from the literature [29] as follows: in $40 \mathrm{~mL}$ water solution of $\mathrm{CuCl}_{2} \times 2 \mathrm{H}_{2} \mathrm{O}\left(\mathrm{c}=0.04 \mathrm{M}, 1.6 \times 10^{-3}\right.$ mole $)$ stirred at room temperature in a $250 \mathrm{~mL}$ three-neck round-bottom flask equipped with a water-bath and a thermometer $16 \mathrm{~g}$ PVP 10,000 were dissolved ( $\mathrm{c}=0.04 \mathrm{M}, 1.6 \times 10^{-3}$ moles) and the $\mathrm{pH}$ was adjusted to 7 by adding $7.4 \mathrm{~mL} \mathrm{NaOH}(\mathrm{c}=0.1 \mathrm{M})$. In order to perform the reduction reaction, approximately 5 times excess of ascorbic acid, $40 \mathrm{~mL}$ solution ( $\mathrm{c}=0.2 \mathrm{M}, 8 \times 10^{-3}$ mole), brought to $\mathrm{pH}=7$ with $18 \mathrm{~mL}$ solution of $\mathrm{NaOH}(\mathrm{c}=0.1 \mathrm{M})$ was then added drop-wise to the copper mixture with vigorous stirring and heating at around $80^{\circ} \mathrm{C}$ for $4 \mathrm{~h}$. Meanwhile 
the color of the reaction mixture changed from milky white to yellow, orange, and finally reddish-brown.

The UV-Vis spectrum of $\mathrm{Cu}$ colloid solution of concentration $7.131 \times 10^{-4} \mathrm{M}$ is presented in Figure 2, together with Atomic Force Microscopy (AFM) images. A maximum of absorption is clearly visible for CuNPs at $591 \mathrm{~nm}$. The shape of the $\mathrm{Cu}$ particles is round with diameters of around $450 \mathrm{~nm}$. The height distribution is $2-7 \mathrm{~nm}$ and the rugosityaresmall $(\mathrm{Sa}=0.55 \mathrm{~nm})$. The highest peak is approximately even with the valley peak, $\mathrm{Sp}=3.3 \mathrm{~nm}, \mathrm{~Sv}=-3 \mathrm{~nm}$, meaning that the CuNPs have a concave-convex lenticular aspect.

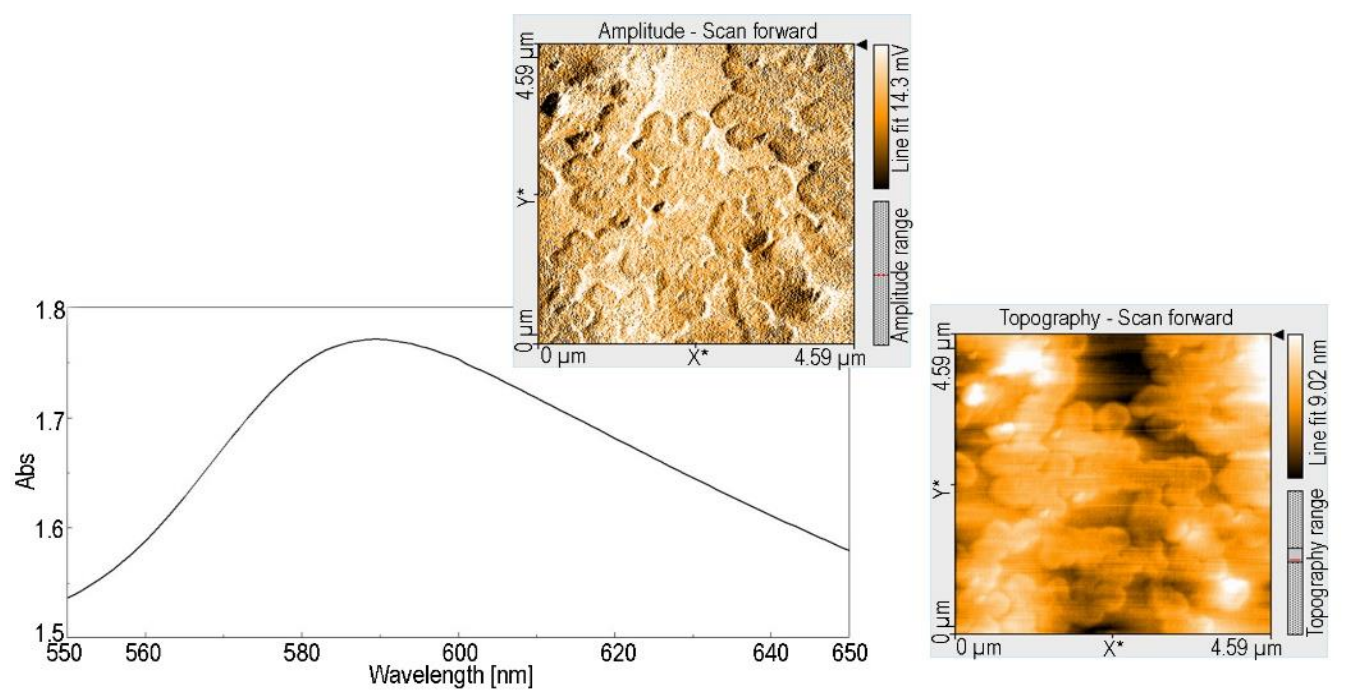

Figure 2. The UV-vis spectrum of $\mathrm{Cu}$ colloid solution $\left(7.131 \times 10^{-4} \mathrm{M}\right)$ and AFM images.

\subsection{Obtaining of Hybrid Complex between CuNPs and TAmPP Porphyrin}

The obtaining of thishybrid was carried outby adding portions of $0.01 \mathrm{~mL}$ water solution of CuNPs $\left(\mathrm{c}=7.131 \times 10^{-4} \mathrm{M}\right)$ to $5 \mathrm{~mL}$ solution of TAmPP in DMSO $\left(\mathrm{c}=3.189 \times 10^{-5} \mathrm{M}\right)$, under stirring for $1 \mathrm{~min}$ at room temperature. The capacity of porphyrin to link the CuNPs was monitored by UV-vis spectrometry (Figure 3). In this case, the Soret band is increasing its intensity due to complex formation. Two clear isosbestic points are forming at $455 \mathrm{~nm}$ and $680 \mathrm{~nm}$, proving the new specie generation.

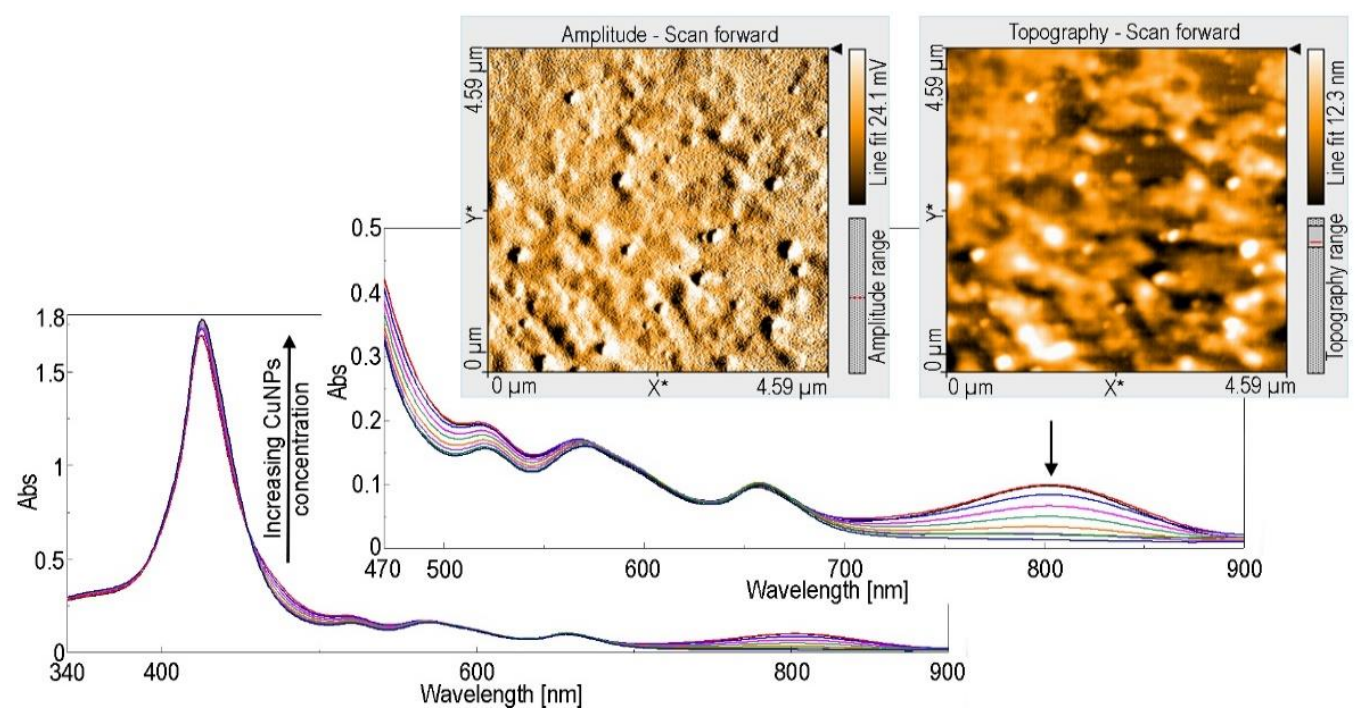

Figure 3. UV-vis spectrometry of CuNPs interference with TAmPP and AFM images of TAmPPCuNPs complex. 
The method is also useful for CuNPs detection in the range of $2.841 \times 10^{-6}$ $8.456 \times 10^{-6} \mathrm{M}$ using TAmPP, sincethere is a linear dependence between the increasing of intensity of absorption on the Soret band and the concentration of CuNPs, as presented in Figure 4 .

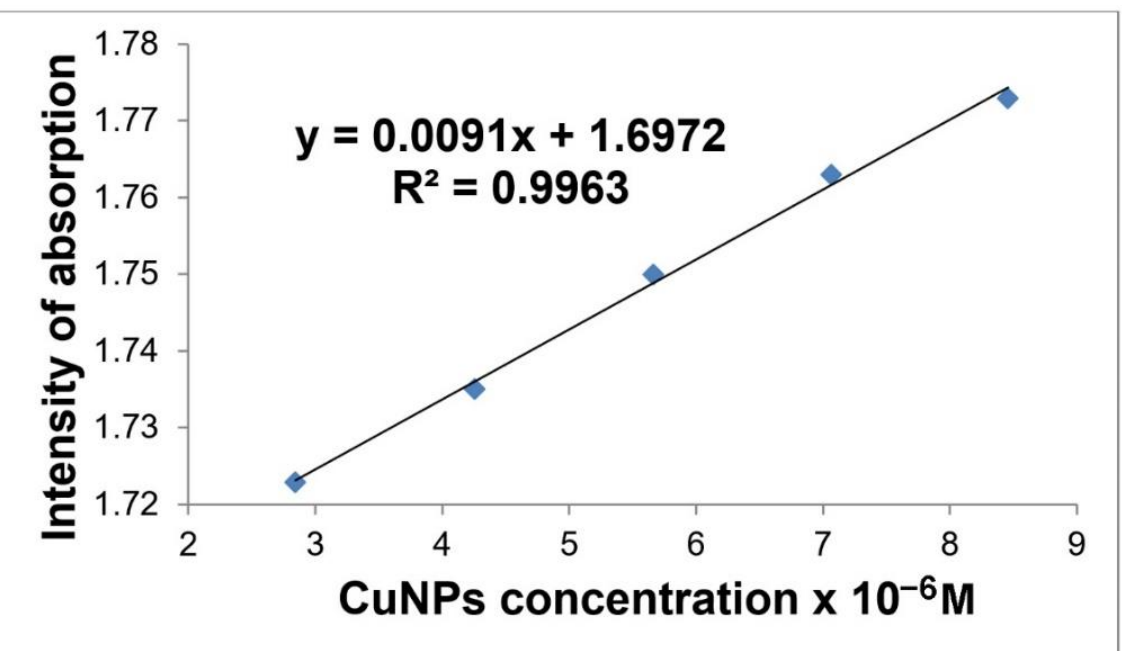

Figure 4. Linear dependence between the increasing of intensity of absorption on the Soret band and the concentration of CuNPs in the range $2.841 \times 10^{-6}-8.456 \times 10^{-6} \mathrm{M}$.

In the case of the CuNPs-TAmPP complex, the morphology of the surface is uneven, height distribution is $3-12 \mathrm{~nm}$, and the rugosity $\mathrm{Sa}=27 \mathrm{~nm}$ is 40 times higher than that of CuNPs, while the highest peak is again approximately even with the valley peak, but 20 times higher in comparison with that of CuNPs, $\mathrm{Sp}=71 \mathrm{~nm}$, and $\mathrm{Sv}=-64 \mathrm{~nm}$. The uniform distribution of round CuNPs on the AFM surface images might indicate a coordination of CuNPs by nitrogen atoms in the core of porphyrin or by amino groups from the periphery of the porphyrin ring.

In order to confirm our presumptions, we synthesized $\mathrm{Cu}$ (II)-TAmPPmetalloporphyrin by classical metalation reaction with dehydrated $\mathrm{CuCl}_{2}$ [30] and compare its UV-Vis, Fluorescence and FT-IR spectra (Figures S1-S3 from Supplementary data) with those of CuNPs-TAmPP complex. As can be seen from the UV-Vis and from the fluorescence spectra, the same position of absorption peaks and of emission peaks, respectively, are to be found in both these analyses for synthesized CuTAmPP and for CuNPs-TAmPP complex, proving that CuNPs is oxidized and the resulting copper(II) cation coordinates into the porphyrin core. FT-IR spectra confirm also for these compared $\mathrm{Cu}$-metalloporphyrin and CuNPsTAmPP complex, the presence of the same bands, the same allure and, in addition, the disappearance in both spectra of the distortion band that is present around $965-990 \mathrm{~cm}^{-1}$ and is a typical $\delta \mathrm{NH}$ band in the spectrum of the porphyrin base. Due to the high reactivity of metal nanoparticles, the observed spectral changes are related to metal insertion in the porphyrin macrocycle, and not simply to an interaction of the CuNP with TAmPP.

\subsection{Obtaining of Mixed Nanoparticles with Cu Core and Pt Shell Pt@CuNPs}

The method was adapted from the literature [19] as described below: to $10 \mathrm{~mL}$ solution CuNPs $\left(3.22 \times 10^{-3} \mathrm{M}\right)$ were added $10 \mathrm{~mL}$ solution $\mathrm{H}_{2} \mathrm{PtCl}_{6} \times 6 \mathrm{H}_{2} \mathrm{O}\left(\mathrm{c}=5.6 \times 10^{-3} \mathrm{M}\right)$, so that a mole ratio of $\mathrm{CuNPs} / \mathrm{H}_{2} \mathrm{PtCl}_{6} \times 6 \mathrm{H}_{2} \mathrm{O}=1: 1.75$ was achieved. The mixture was stirred at room temperature for $20 \mathrm{~min}$ until the color turned dark-grey. The obtained nanoparticles were washed with waterfive times and with ethanol twice. The UV-Vis spectrum of Pt@CuNPs in water having the maximum of absorption at $\lambda=205 \mathrm{~nm}$ is presented in Figure 5 together with the 2D and 3D-AFM images revealing its morphological, organization. 


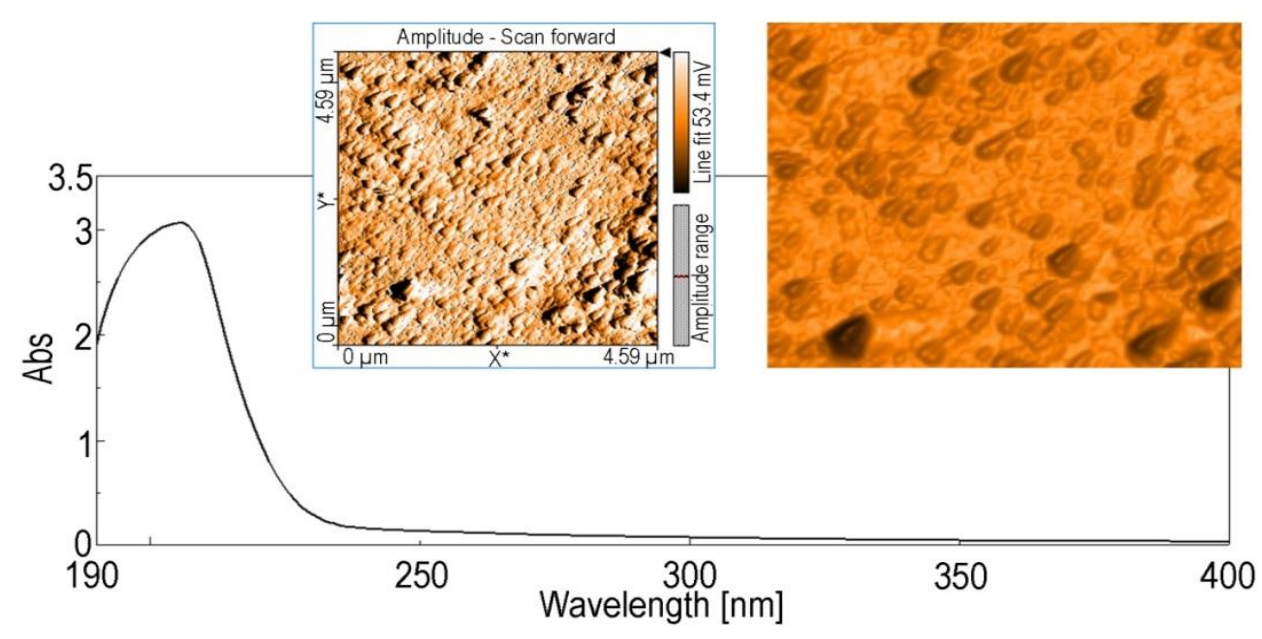

Figure 5. The UV-Vis spectrum of Pt@CuNPs in water, together with 2D and 3D-AFM images.

The AFM characteristics are completely different than the shape and size of CuNPs. By covering the $\mathrm{Cu}$ particles with platinum, the mixed Pt@CuNPs particles restructured their shape from round to isosceles triangles, and the size was significantly reduced from diameter of $450 \mathrm{~nm}$ to sides in the range of $150-180 \mathrm{~nm}$. The recent literature is dedicated to the subject of the volume shrinkage of the inner cores, after covered with Pt shells. The impact of the lattice strainson the surface electronic structure of Pt was investigated with X-ray photoelectron spectroscopy (XPS) and high-resolution valence band (XPS), showing lattice compression [31]. On the other hand, density functional theory calculations revealed that Pt shell undergo large tensile strains [32].

An explanation of the compressive strain effects of the Pt film was already attempted [33], and is based on the consideration that, due to the interaction of the Pt film with the underlying metal substrate (in our case $\mathrm{Cu}$ having smaller interatomic spacing), the platinum atoms adopt the interatomic distances of the $\mathrm{Cu}$ substrate lattice morethan its normal spacing. As a consequence the thin film of platinum is subjected to compressive strain.

All the so-formed particles are oriented in the same direction and are accompanied by very small spherical particles of $30 \mathrm{~nm}$ that are probably unreacted CuNPs. 3D AFM images show triangular-based prisms with height distribution in the domain 8-21 nm. Regarding the triangular shape having the same orientation, thiswas found also for copper-gold, reported for the first time in the paper [34], for gold [35], for copper [36], and even highly ordered triangular particles were displayed, [37] as reported in our case.

\subsection{Obtaining of Hybrid Complex between Pt@CuNPs and TAmPP Porphyrin}

The complex between Pt@CuNPs and TAmPP porphyrin wasperformed in the same way as described in the case of CuNPs, by adding portions of $0.01 \mathrm{~mL}$ water solution of Pt@CuNPs $\left(\mathrm{c}=7.25 \times 10^{-4} \mathrm{M}\right)$ to $5 \mathrm{~mL}$ solution of TAmPP in DMSO $\left(\mathrm{c}=3.265 \times 10^{-5} \mathrm{M}\right)$ under stirring for $1 \mathrm{~min}$ at room temperature. The capacity of porphyrin to link the Pt@CuNPs was monitored by UV-vis spectrometry (Figure 6). As already reported for CuNPs, in this case the Soret band is also increasing its intensity due to complex formation and a single isosbestic point is formed at $453 \mathrm{~nm}$ the allure of the spectrum being similar with that from Figure 3, despite the lack of a second isosbestic point on the $Q$ bands. The large variation in $Q$ band not accompanied by the same in B-band might be the result of amino-functional group interference in the formation of the complex. It is known that UVvis changes are more significant on $Q$ bands if porphyrins act due to peripheral interactions. 


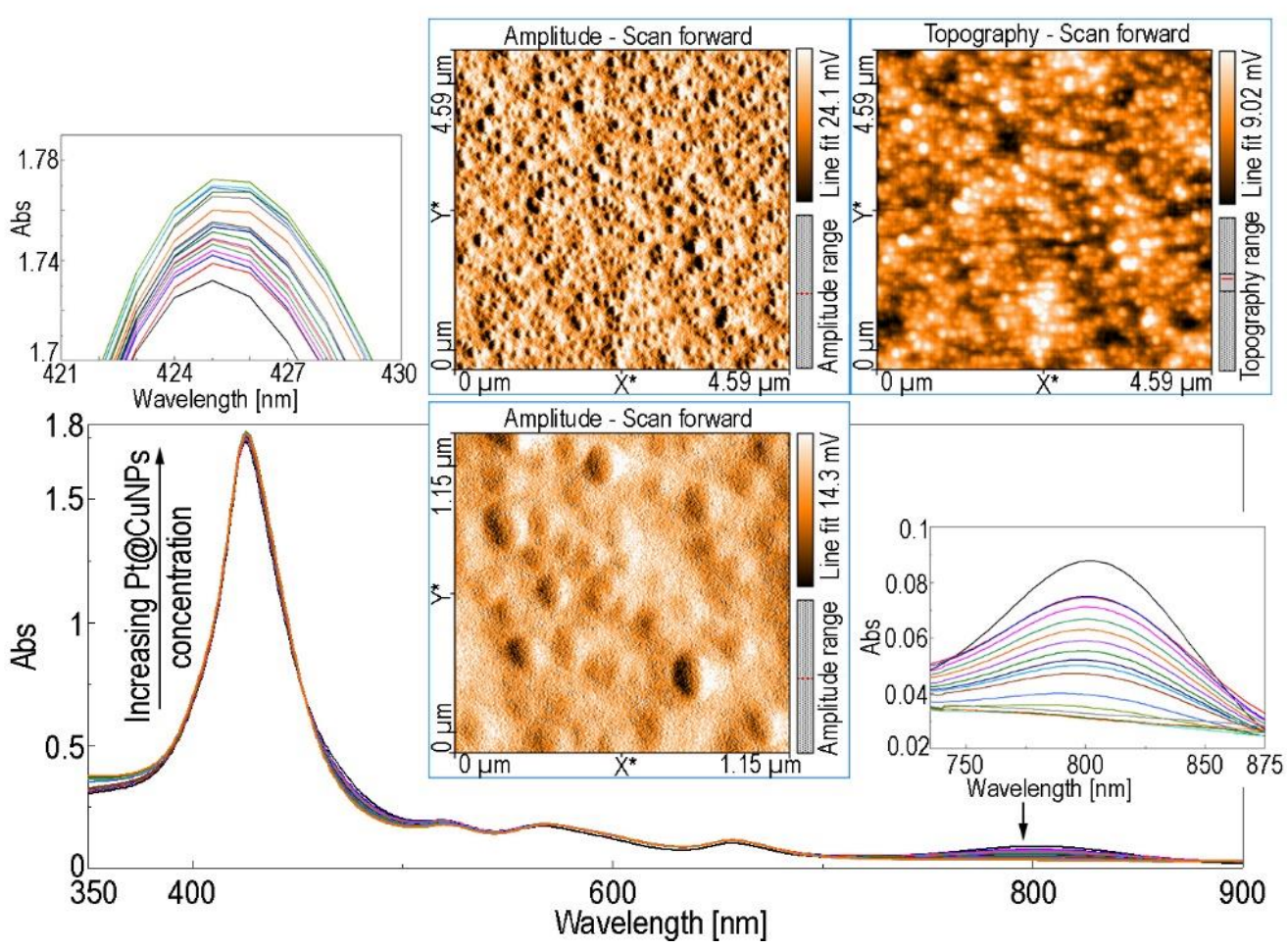

Figure 6. UV-Vis spectrometry of obtaining the hybrid complex between Pt@CuNPs and TAmPP porphyrin and AFM images of complex.

The AFM images show that the hybrid between Pt@CuNPs and TAmPP porphyrin have ovoid particles with sizes in the range of $85-120 \mathrm{~nm}$ which randomly dispersed containwith large voids, as can be seen in topography scan (Figure 6). The rugosity analysis offers a very interesting aspect. The $\mathrm{Sv}$ is around $-7 \mathrm{~nm}$, and the $\mathrm{Sp}$ is of $+7 \mathrm{~nm}$, meaning that the ovoid systems are half above and half below the plane.

\subsection{Synthesis of the Platinum Colloid}

Obtaining of PtNPswas carried outas described in literature [38], as follows: in $30 \mathrm{~mL}$ water was dissolved $0.029 \mathrm{~g} \mathrm{H}_{2} \mathrm{PtCl}_{6} \times 6 \mathrm{H}_{2} \mathrm{O}\left(\mathrm{c}=1.6 \times 10^{-3} \mathrm{M}, 7.07 \times 10^{-5}\right.$ moles $)$. To this solution it was added $0.035 \mathrm{~g}$ trisodium citrate $\left(1.35 \times 10^{-4}\right.$ moles $)$. The mixture was stirred at $1000 \mathrm{rpm}$ for $30 \mathrm{~min}$. Then, $0.7 \mathrm{~mL} \mathrm{NaBH}_{4}\left(\mathrm{c}=0.05 \mathrm{M}, 1.32 \times 10^{-3}\right.$ moles$)$ was added to the above mixture and stirred for $1 \mathrm{~h}$, at ambient temperature. The color changed from slightly yellow to brownish yellow at the end of the reaction.

The UV-vis spectrum and the morphology of the surface of platinum nanoparticles obtained are represented in Figure 7. The PtNPs are spherical of around $85 \mathrm{~nm}$, not aggregated, with narrow height distribution of $3-7 \mathrm{~nm}$, the rugositySa $=2 \mathrm{~nm}$, and a very symmetrical distribution of highest peak $(\mathrm{Sp}=8.1 \mathrm{~nm})$, and of lowest valley $(\mathrm{Sv}=-7 \mathrm{~nm})$. 


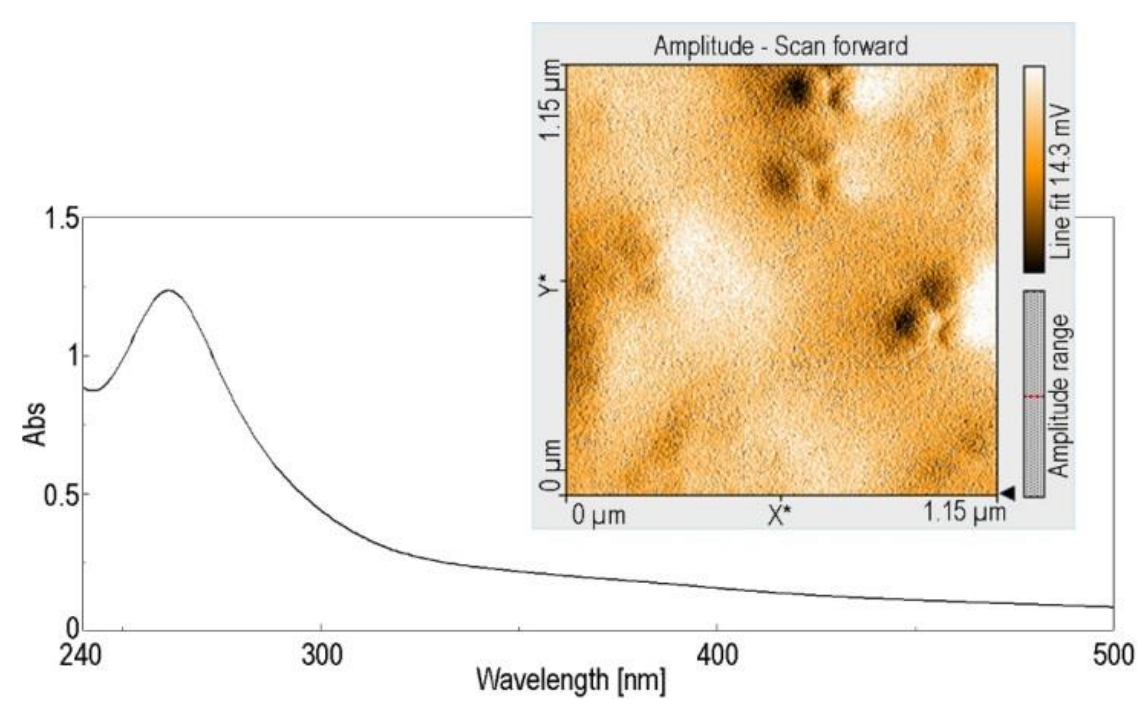

Figure 7. The UV-Vis spectrum and the 2D AFM image of the PtNPs.

\subsection{Method for Obtaining of the Hybrid Material between TAmPP and PtNPS}

To $5 \mathrm{~mL}$ TAmPP solution in DMSO $\left(\mathrm{c}=3.1366 \times 10^{-5} \mathrm{M}\right)$ portions of $0.01 \mathrm{~mL}$ PtNPs $\left(c=3.94 \times 10^{-4} \mathrm{M}\right)$ were added. The mixtures were stirred for $60 \mathrm{~s}$ and UV-Vis spectra were recorded (Figure 8).

The morphology of the surface of TAmPP-PtNPs (represented in detail (a) of Figure 8) is completely modified in comparison with both PtNPs (detail Figure 7) and with TAmPP (represented in detail (b) of Figure 8).

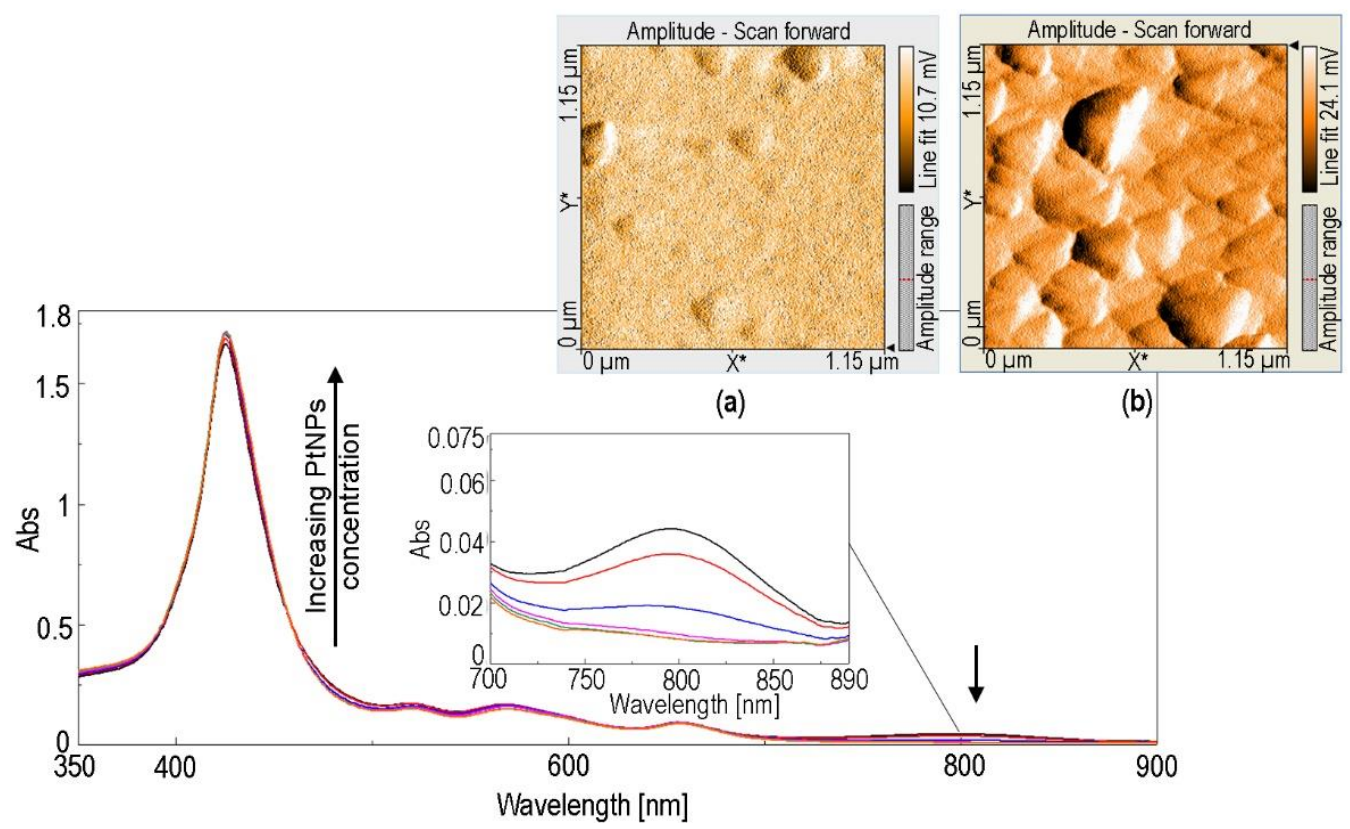

Figure 8. Overlapped UV-Vis spectra, monitoring the obtaining of TAmPP- PtNPs hybrid material. Detail (a): AFM image of TAmPP- PtNPs hybrid material. Detail (b): AFM image of TAmPP.

As clearly presented, dispersed triangular forms with sides of $100 \mathrm{~nm}$ are formed by TAmPP-PtNPs hybrid material (Figure 8, detail (a)), these being different in size and shape from both the spherical nanoparticles of platinum (Figure 7) and the compact aggregates based on larger triangular building-blocks of TAmPP (with sides of $200 \mathrm{~nm}$, as imaged in Figure 8, detail (b)). 


\subsection{X-ray Diffraction (XRD) Characterization of the CuNPs, PtNPs and Platinum Covered Copper Core Nanoparticles (Pt@CuNPs)}

From the X-ray diffraction measurements, the crystalline form of the three metallic nanoparticlescan be noticed. For the CuNPs nanomaterial, the identification was carried outby using JCPDS No. 00-001-1241 and the most intense peak can be found at $47.54^{\circ}$. For the PtNPs nanomaterial, the identification was carried outby using JCPDS No. 00-001-1194 and the most significant peak is located at $45.49^{\circ}$, as can be seen in Figure 9. Both of these materials belong to cubic crystal system, space group $=\mathrm{Fm} 3 \mathrm{~m}$, having crystallographic parameters for $\mathrm{Cu}$ a $(\AA)=\mathrm{b}(\AA)=\mathrm{c}(\AA)=3.5970\left(\right.$ cell volume $\left.46.54 \times 10^{6} \mathrm{pm}^{3}\right)$ and respectively for Pt a $(\AA)=b(\AA)=\mathrm{c}(\AA)=3.9161$ (cell volume $\left.60.06 \times 10^{6} \mathrm{pm}^{3}\right)$.

The Pt@CuNPs nanomaterial has the most intense peak at 39.64 (attributed to Pt with Miller indices (111) but split in two due to the interactions taking place at the $\mathrm{Cu}-\mathrm{Pt}$ interface. The peak identified as (200) belongs both to $\mathrm{Cu}$ and to Pt. The peak marked (220) is attributed to $\mathrm{Cu}$. The (311) peak is attributed also to both $\mathrm{Cu}$ and $\mathrm{Pt}$ and split (on $\mathrm{XRD}$ diagram of $\mathrm{Pt}$ it can be noticed a shoulder on its corresponding peak). The peaks noted with a star were identified by the help of JCPDS No. 00-023-0221 as belonging to oxidized system $\mathrm{CuPt}_{3} \mathrm{O}_{6}$. It is to be noticed that an oxidation process could occur regarding the samples provided for $\mathrm{XRD}$, sincethese samples were fast obtained only for this investigations and the syntheses were conducted without nitrogen pillow and without using the PVP as stabilizing agent.

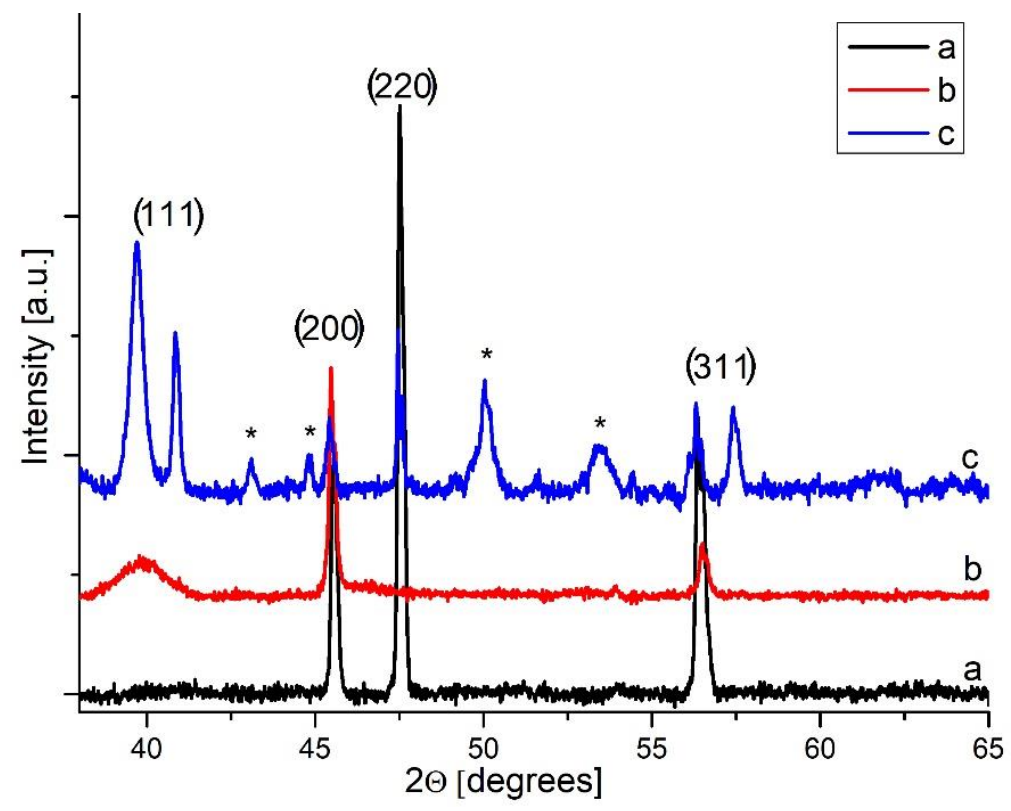

Figure 9. XRD diagrams for: (a) CuNPs; (b) PtNPs; (c) Pt@CuNPs.

2.15. Emission-Scanning Electron Microscopy-(SEM) Characterization of the CuNPs, PtNPs and (Pt@CuNPs) Nanoparticles

The SEM/EDAX measurements reveal the main cubic crystallization form and the presence of required elements in EDAX detail (Figure 10). The dimension of the particle is significantly smaller in the case of (Pt@CuNPs) nanoparticles than in the case of PtNPs, probably due to the same effect of the volume shrinkage (already explained in detail in Section 2.10). In case of CuNPs, plackets emitting light are observed (Figure 10a). 


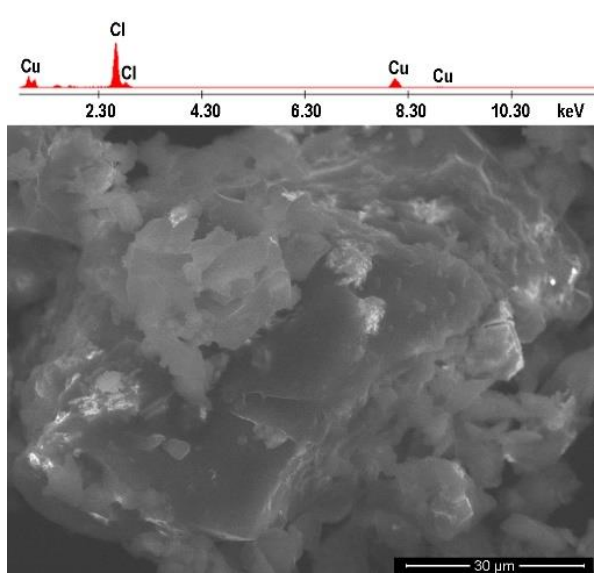

(a)

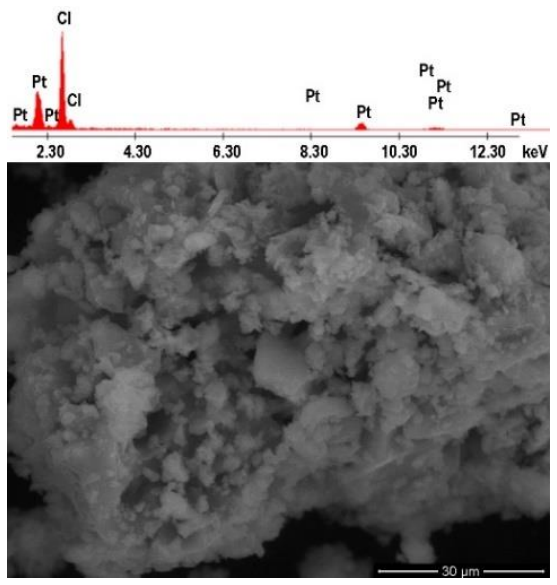

(b)

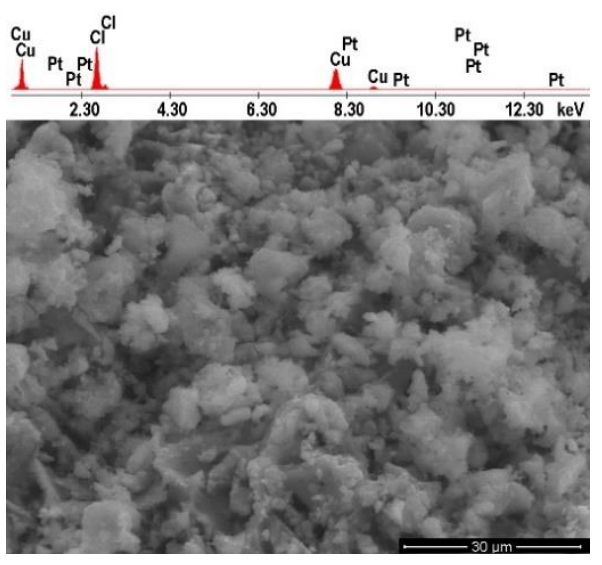

(c)

Figure 10. SEM images with EDAX in detail for: (a) CuNPs; (b) PtNPs; (c) Pt@CuNPs.

\section{Results and Discussions}

\subsection{Detection of UA Using Acidified TAmPP Solution in DMSO}

Asolution of $5 \mathrm{~mL}$ TAmPP in DMSO $\left(\mathrm{pH}=4.5\right.$ realized with $\mathrm{HCl}$ ) having $3.3467 \times 10^{-5} \mathrm{M}$ concentration is treated in steps with $0.01 \mathrm{~mL}$ solution of UA in DMSO of $2.974 \times 10^{-5} \mathrm{M}$ concentration.

The changes in UV-Vis spectra shape and position were registered and represented in Figure 11. By increasing the UA concentration, the Soret band and the QII and QIII bands are decreasing in intensity, while QI is significantly increasing its intensity and, hypsochromically shifted. In the UV-Vis spectra, a clear isosbestic point at the $682 \mathrm{~nm}$ wavelength on the shoulder of the QII band can be noticed. The dependence between the intensity of absorption measured at Soret band $(425 \mathrm{~nm})$ and the UA concentration is linear in the range of $0.582 \times 10^{-6}-5.6472 \times 10^{-6} \mathrm{M}$, as presented in Figure 12 .

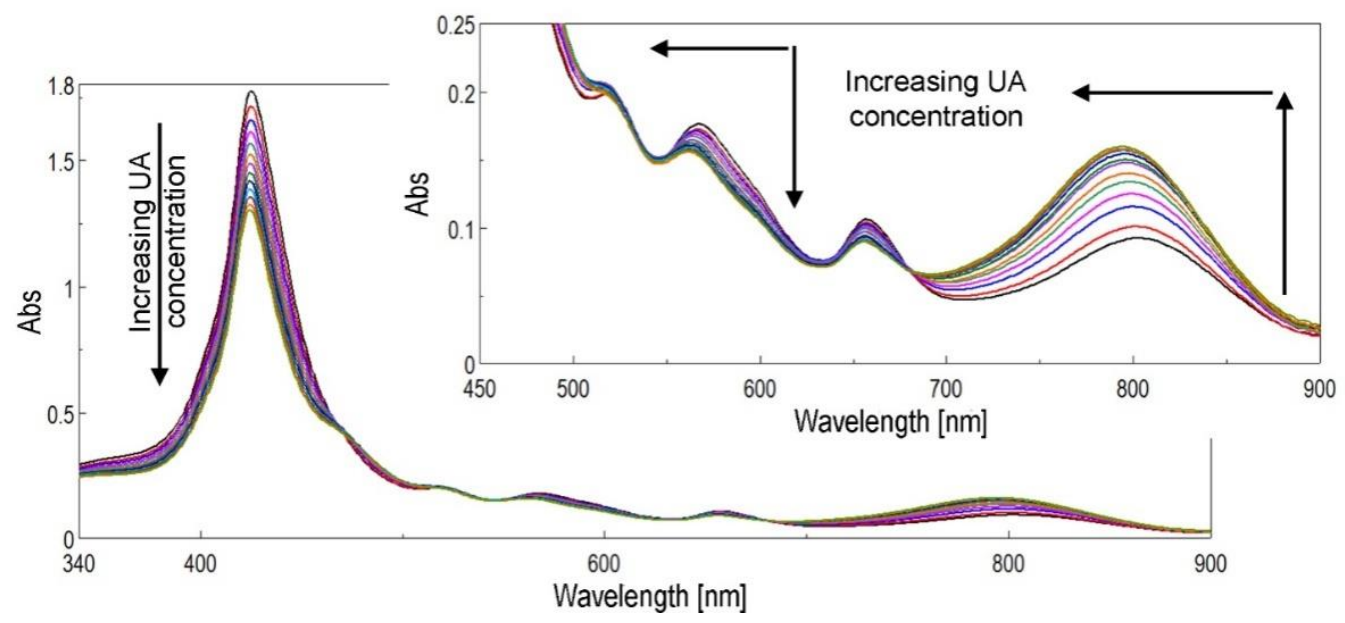

Figure 11. The changes in UV-Vis spectra shape and position during the adding of UA to TAmPP solution in DMSO. 


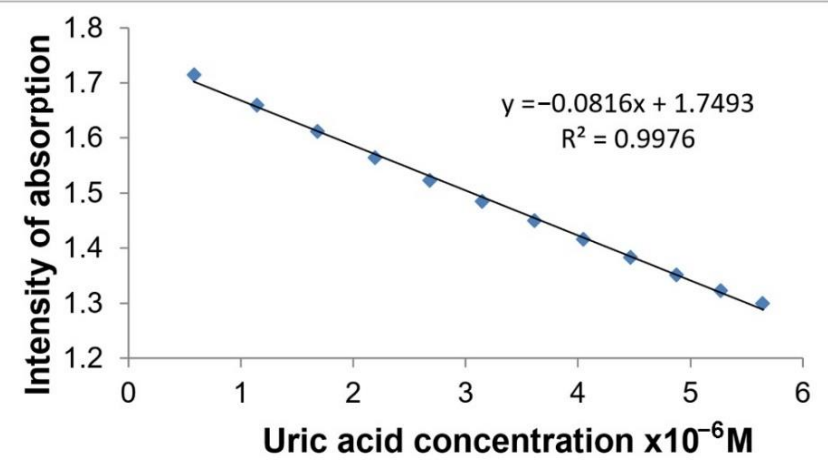

Figure 12. The dependence between the intensity of absorption measured for TAmPP at Soret band (425 nm) and the UA concentration.

\subsubsection{Interference Study}

The effect of interfering species usually present together with UA in the targeted media (human serum and urine), such as:glucose (Glu), ascorbic acid (AA), $\mathrm{NaCl}, \mathrm{KCl}$, $\mathrm{CH}_{3} \mathrm{COONa}, \mathrm{MgSO}_{4}, \mathrm{KI}$, lactic acid (LA), sodium salicylate (SS), were assessed in the presence of UA and presented in Figures 13 and 14.

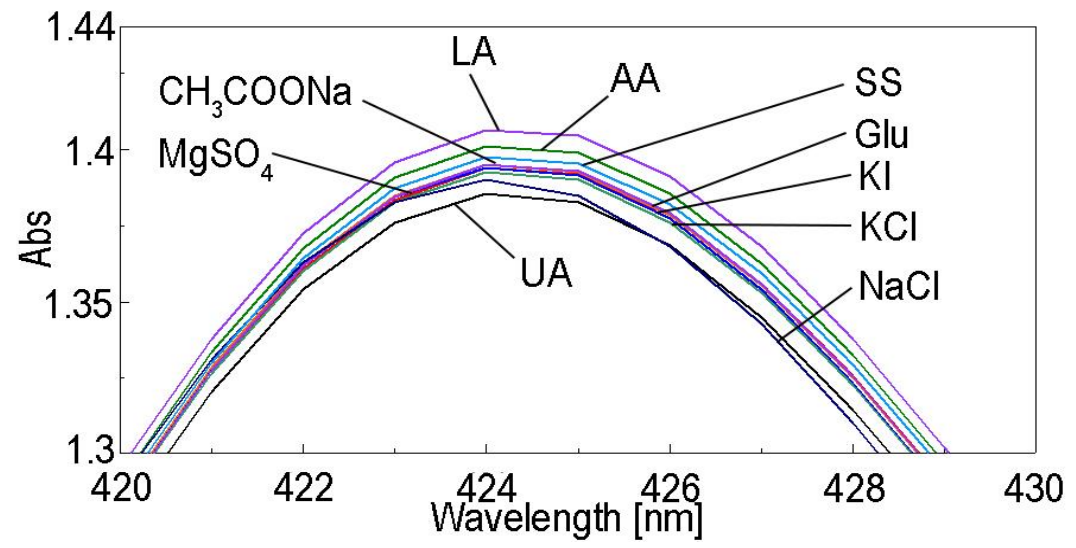

Figure 13. Overlapped UV-Vis spectra representing the influence of diverse interfering species (at concentrations 1000-fold higher than UA) on the TAmPP material: glucose (Glu), ascorbic acid (AA), $\mathrm{NaCl}, \mathrm{KCl}, \mathrm{CH}_{3} \mathrm{COONa}, \mathrm{MgSO}_{4}, \mathrm{KI}$, lactic acid (LA), and sodium salicylate (SS).

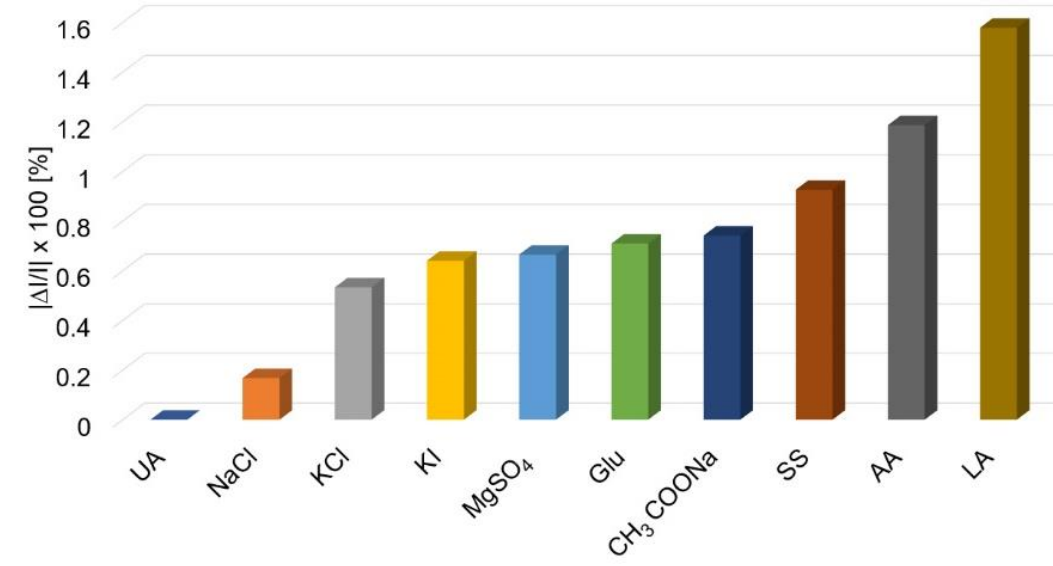

Figure 14. Average percentage errors for UA optical detection using TAmPP, introduced by different interferences. 
To freshly prepared portions of $3 \mathrm{~mL}$ TAmPP complex with UA were added in each case $0.5 \mathrm{~mL}$ of solutions of interfering species at a concentration of $1 \times 10^{-3} \mathrm{M}$, so that this concentration represents approximately 1000 -fold increase as compared to the UA detected concentration domain. Each sample was stirred for $1 \mathrm{~min}$ and the UV-vis spectra were recorded. Each measurement was performed three times. The average percentage errors for UA detection are calculated as $|\Delta \mathrm{I}| / \mathrm{I} \times 100$ (where I represents the absorption intensity of the sample containing $\mathrm{UA}$ and $|\Delta \mathrm{I}|$ is the difference in module between absorption intensity of UA and of each studied interference specie, as displayed in Figure 14.

\subsubsection{Mechanism of Detection of Uric Acid by Solely Porphyrin}

Keto-enol tautomerism is a property of uric acid that suffers equilibrium between the lactam and the lactim forms. The lactim form has aromatic structure (Figure 15) but uric acid is crystalline and stable in its lactim form. Since all of the detection experiments have been performed in aqueous solutions at $\mathrm{pH}$ around 4.5, UA and TAmPP porphyrin are both protonated and the lactim form might be in equilibrium with urate ion. The mechanism of recognition can thus be based by a proton transfer from the deprotonatedTAmPP porphyrin toward the urate ion, with regeneration of lactim form.

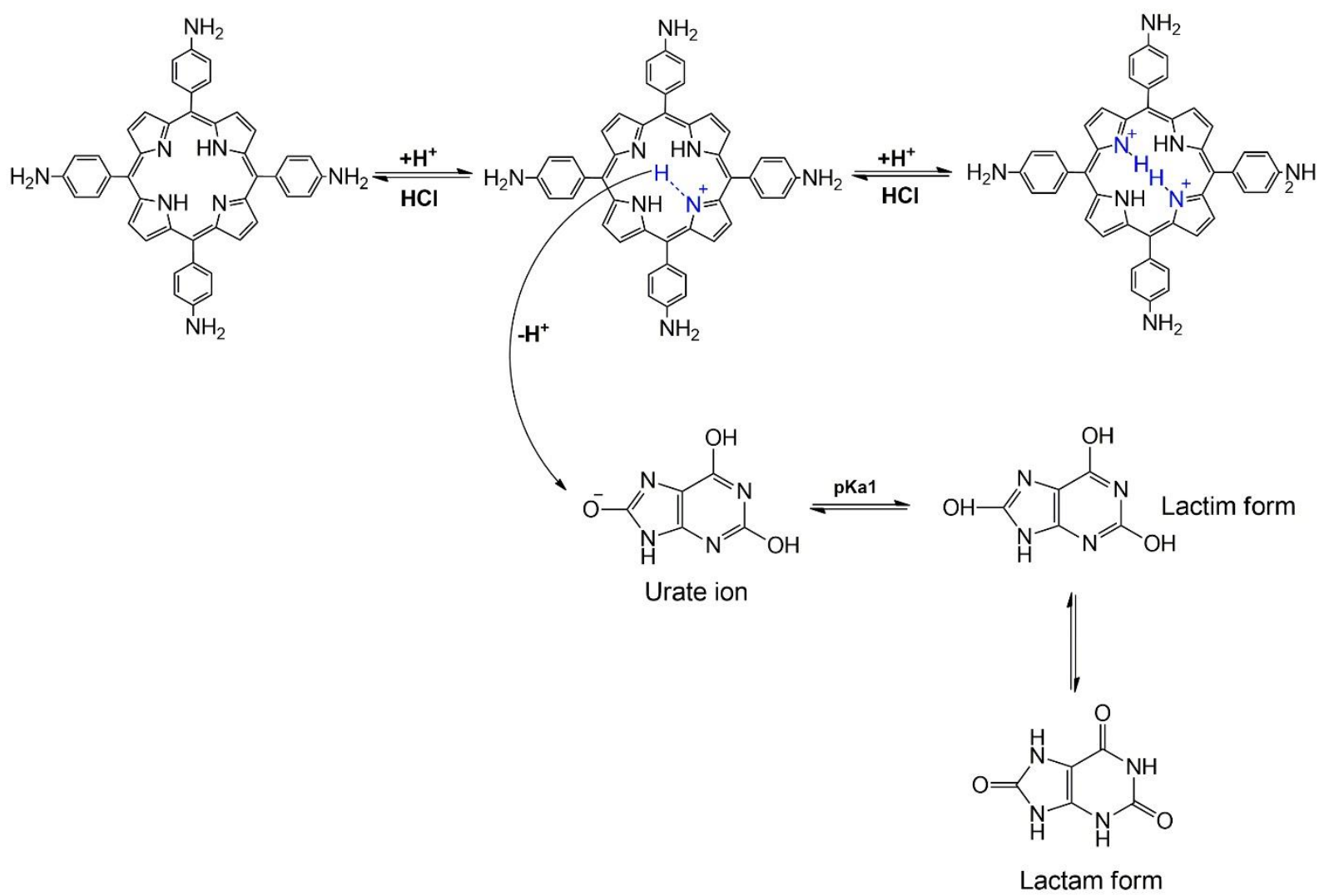

Figure 15. The mechanism ofuric acid detection based on a proton transfer from the protonated TAmPP porphyrin toward the urate ion, with regeneration of lactim form.

\subsection{Detection of Uric Acid with TAmPP-CuNPs Hybrid Material}

Detection of UA using TAmPP-CuNPs hybrid material is presented in Supplementary material, because the detected domain (Figures S4 and S5) is overlapping with the detection realized using TAmPP-Pt@CuNPs and TAmPP-PtNPs. In addition, the main disadvantage by using TAmPP-CuNPs hybrid material is that $\mathrm{CH}_{3} \mathrm{COONa}$ and sodium salicylate are significantly interfering with UA detection (Figures S6 and S7), if present in 1000 fold higher concentrations than UA. 


\subsection{Detection of UA Using TAmPP-Pt@CuNPs Hybrid Material}

To 5 mL TAmPP-Pt@CuNPs hybrid complex acidified with $\mathrm{HCl}(\mathrm{c}=0.01 \mathrm{M})$ to $\mathrm{pH}=4.5$ portions of $0.01 \mathrm{~mL} \mathrm{UA}$ in DMSO $\left(\mathrm{c}=2.974 \times 10^{-4} \mathrm{M}\right)$ were added and stirred for $1 \mathrm{~min}$ at room temperature. The UV-vis spectra were registered as represented in Figure 16. The UV-Vis absorption spectrum shows the same shifts and changes as in the case of the UA with TAmPP-CuNPs complex, as shown in Figure S4 in Supplementary material.

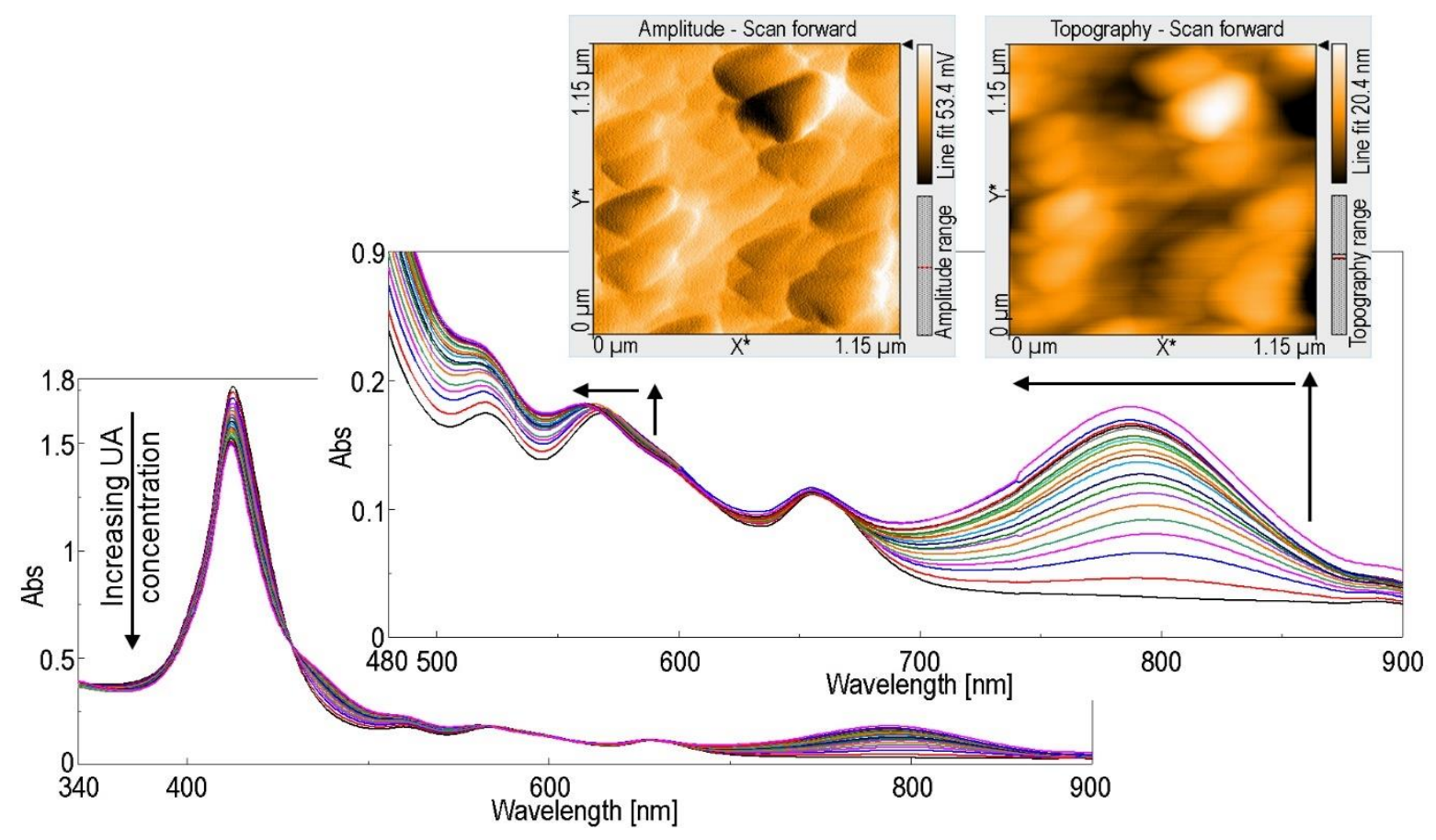

Figure 16. The UV-vis spectra registered by adding UA to TAmPP- Pt@CuNPs hybrid material in DMSO solution; AFM images of TAmPP- Pt@CuNPs hybrid material after exposure to UA.

The AFM images taken after TAmPP- Pt@CuNPs hybrid material was exposed to increased concentrations of UA are presented indetail in Figure 16. In this case we obtained highly-ordered supramolecular architectures of triangular aspect with equal sides of $211 \mathrm{~nm}$, self-associating due to stacking of the large, flat core of the porphyrins, both caused by hydrogen bonding between an acceptor from internal $\mathrm{N}$ and a donor from $\mathrm{NH}$ functionalities from both porphyrin periphery and uric acid, favored by acidic environment. On the other hand, these aggregates are similarly organized with nematic liquid crystals that follow one directory axis, in which both the polarizability and the refraction index are different in comparison with the other two axes [39]. Additionally, the distance between molecules is not uniform, independent of the direction of measuring. The rugosity has a small value $\mathrm{Sa}=2.6 \mathrm{~nm}$, but the surface reveals the formation of voids, favoring detection (see AFM image -topography). Height distribution is in the range of nanomaterials of $8-17 \mathrm{~nm}$.

To determine the dependence of the absorption intensity of TAmPP- Pt@CuNPs hybrid material in function of UA concentration, we represent the changes in UV-vis spectra both at $425 \mathrm{~nm}$ (on Soret band) and also at $790 \mathrm{~nm}$ (on QI band). In the first case we have a decreasing linear dependence in the range of $1.68 \times 10^{-6}-8.08 \times 10^{-6} \mathrm{M}$ and in the second an increasing linear dependence in a narrower range of $1.13 \times 10^{-6}-5.48 \times 10^{-6} \mathrm{M}$, both characterized by very good correlation coefficients, as represented in Figure 17. 


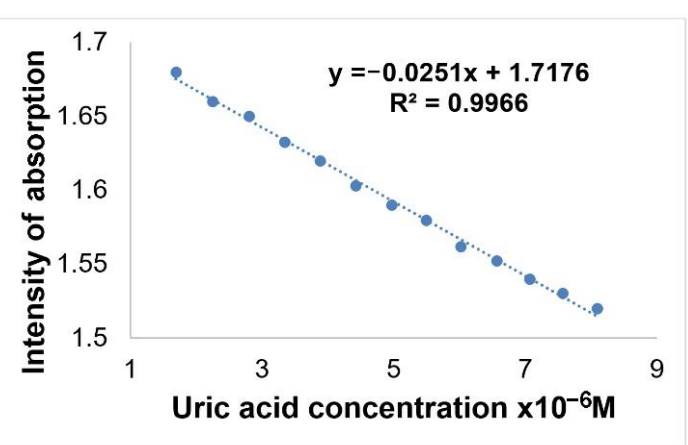

(a)

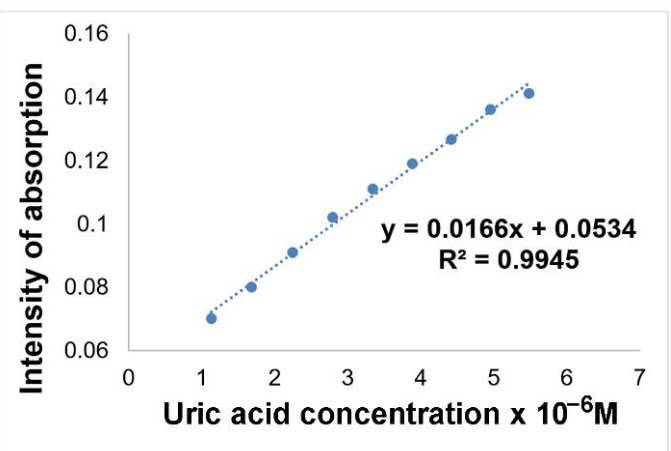

(b)

Figure 17. The linear dependence of the absorption intensity of TAmPP-Pt@CuNPs hybrid material measured as function of UA concentration: (a) on theSoret band; (b) on the QI band.

\subsubsection{Interference Study}

The effect of interfering species was studied taking into consideration the same ions and molecules as described in Section 3.1.1, and representing the obtained UV-Vis spectra (Figure 18). To freshly prepared portions of $3 \mathrm{~mL}$ TAmPP-Pt@CuNPs hybrid material containing $0.1 \mathrm{~mL} 1 \times 10^{-5} \mathrm{M}$ UA in DMSO were added in each case $1 \mathrm{~mL}$ of solutions of interfering species at a concentration of $1 \times 10^{-3} \mathrm{M}$, to obtain 1000 -fold increased concentrations as compared to the UA detected concentration domain. The average percentage errors for UA detection are displayed in Figure 19.

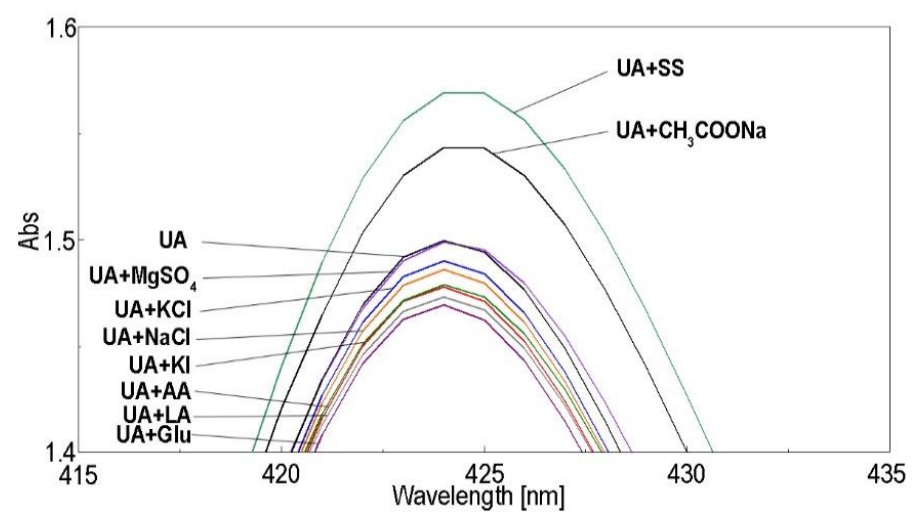

Figure 18. Overlapped UV-Vis spectra representing the influence of diverse interfering species: glucose (Glu), ascorbic acid (AA), $\mathrm{NaCl}, \mathrm{KCl}, \mathrm{CH}_{3} \mathrm{COONa}, \mathrm{MgSO}_{4}, \mathrm{KI}$, lactic acid (LA), sodium salicylate (SS), on the TAmPP-Pt@CuNPs hybrid complex at concentrations 1000-fold higher than UA.

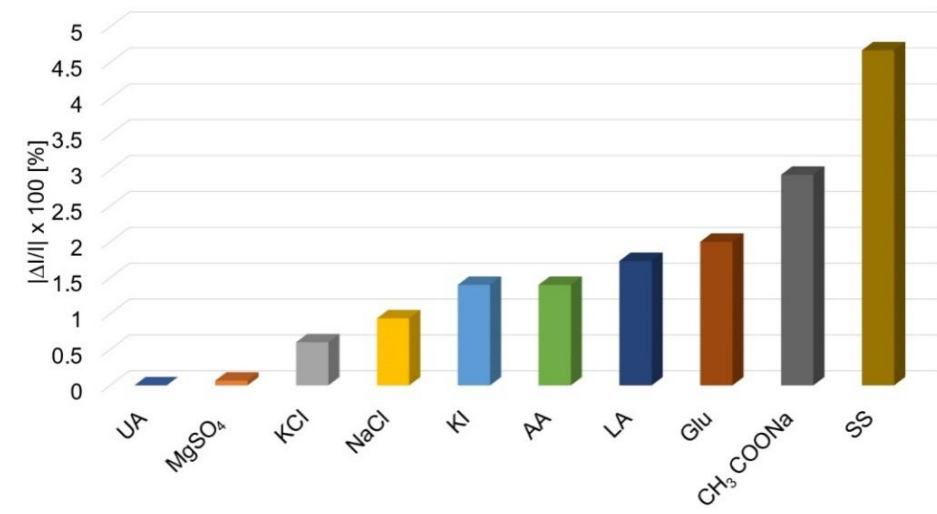

Figure 19. Average percentage errors for UA optical detection using TAmPP-Pt@CuNPs hybrid complex hybrid complex, introduced by different interferences. 
Figures 18 and 19 showed that using TAmPP-Pt@CuNPs hybrid material a better accuracy is obtained than in the case of TAmPP-CuNPs hybrid material, even if in case of $\mathrm{CH}_{3} \mathrm{COONa}$ and SS, the average percentage errors are 2.92 and 4.66 , respectively.

\subsection{Detection of UA Using TAmPP-PtNPs Hybrid Complex}

The detectionwas carried outalso in acidified medium $\mathrm{pH}=4.5$ by adding portions of $0.01 \mathrm{~mL}$ UA in DMSO $\left(\mathrm{c}=2.974 \times 10^{-4} \mathrm{M}\right)$ to $5 \mathrm{~mL}$ of TAmPP-PtNPs hybrid complex at room temperature. The UV-Vis spectra were registered, after 1 min stirring, as represented in Figure 20.

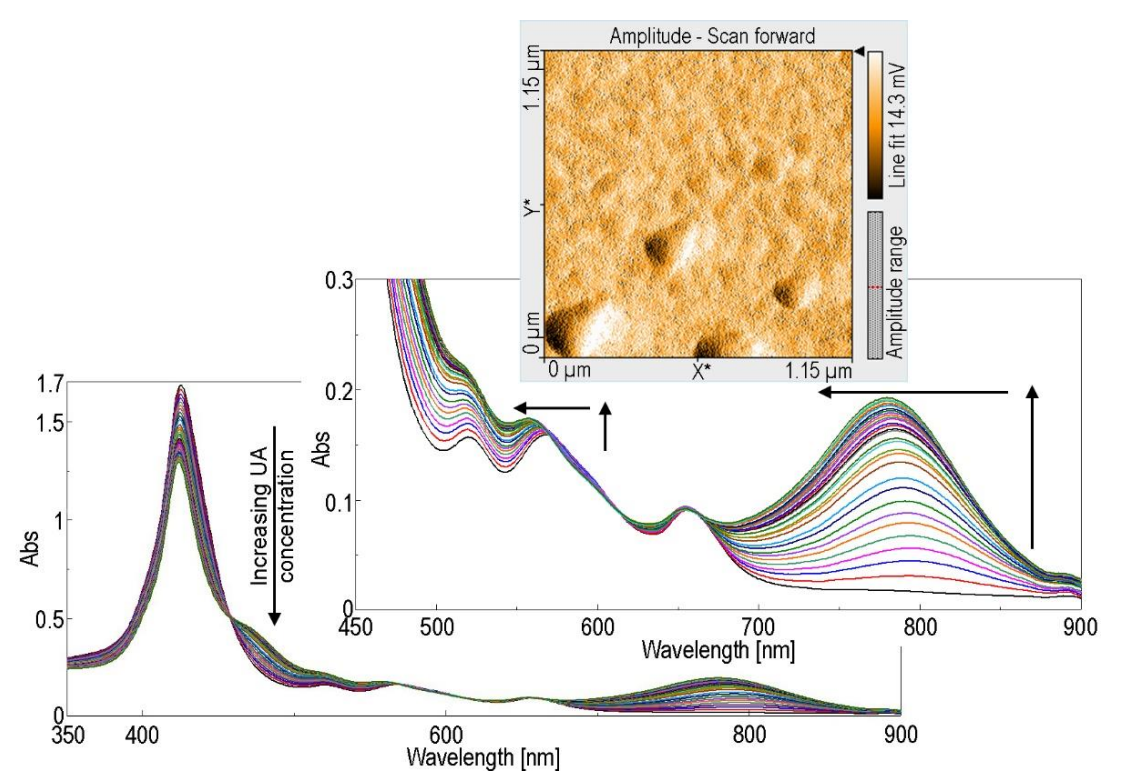

Figure 20. Overlapped UV-Vis spectra of complex TAmPP-PtNPs after continuous adding of uric acid. In detail AFM image of the material after treatment with uric acid.

As can be seen from Figure 20, a very clear isosbestic point was formed on the Soret band at $460 \mathrm{~nm}$, accompanied by other three ones located at $570 \mathrm{~nm}, 610 \mathrm{~nm}$, and $670 \mathrm{~nm}$. The intensity of the Soret band of the TAmPP-PtNPs complex decreased linearly in the range $6.1958 \times 10^{-6}-1.5763 \times 10^{-5} \mathrm{M}$ UA concentration (Figure 21), while the intensity of the QI band is continuously increasing with UA concentration. The precision of measurements is appropriate and the domain of UA concentrations is wider than all the other cases and complete the field detected by TAmPP-Pt@CuNPs hybrid material $\left(1.68 \times 10^{-6}-8.08 \times 10^{-6} \mathrm{M}\right)$.

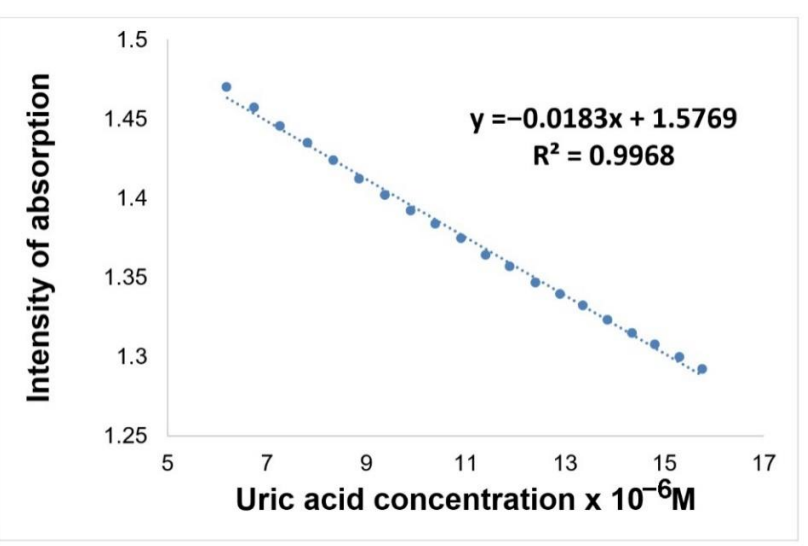

Figure 21. Linear dependence between absorption intensity of TAmPP-PtNPs hybrid material and uric acid concentration. 


\section{Interference Study}

The effect of interfering species was carried outusing the same ions and molecules having 1000-fold increased concentrations in comparison with the UA, as described in Sections 3.1.1 and 3.3.1. The obtained UV-Vis spectra were drawn in Figure 22. The average percentage errors for UA detection are displayed in Figure 23.

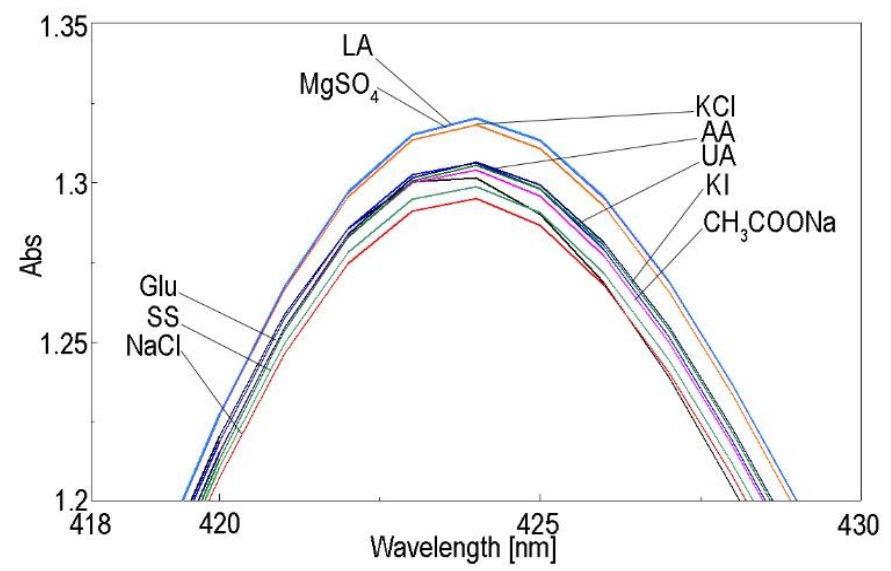

Figure 22. Superposed UV-Vis spectra representing the influence of the following interfering species: glucose (Glu), ascorbic acid (AA), $\mathrm{NaCl}, \mathrm{KCl}, \mathrm{CH}_{3} \mathrm{COONa}, \mathrm{MgSO}_{4}, \mathrm{KI}$, lactic acid (LA), and sodium salicylate (SS) on the TAmPP-PtNPs hybrid complex at concentrations 1000-fold higher than UA.

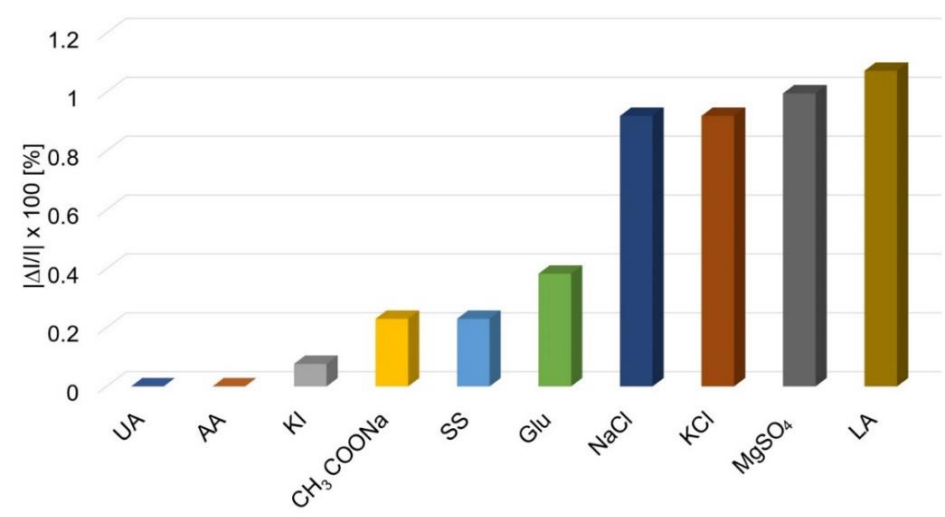

Figure 23. Average percentage errors for UA optical detection using TAmPP-PtNPs complex, introduced by different interferences.

The complex TAmPP-PtNPs offers the best and highly stable response for UA in the presence of interference species present in human environment, all of the tested species introducing average percentage errors below $1.05 \%$.

\subsection{Real Test on Synthetic Solution Using TAmPP-PtNPs Complex}

A synthetic solution containing UA of $8 \times 10^{-6} \mathrm{M}$ concentration, gave a result of $8.1 \times 10^{-6} \mathrm{M}$, and the same solution of UA containing AA, KI, SS, Glu and $\mathrm{NaCl}$ interferences $\left(8 \times 10^{-4} \mathrm{M}\right.$ concentration) gave a result of $8.19 \times 10^{-6} \mathrm{M}$. These values confirm a maximum error of $2.3 \%$ when using aTAmPP-PtNPs complex that can be considered for UA sensor formulations.

\section{Conclusions}

Starting from the knowledge that the average levels of uric acid in serum and urine for healthy human are between 120 to $420 \mu \mathrm{M}$ and from 1.48 to $4.43 \mathrm{mM}$, respectively, our approach was to develop new series of selective and sensitive sensors for UA [5]. 
Several hybrid nanomaterials based on 5,10,15,20-tetrakis-(4-amino-phenyl)-porphyrin andCuNPs, PtNPs, respectively, Pt@CuNPs were obtained and tested for their capacity to detect uric acid from solutions by an optical method, which can be a fast and cheap method and to increase selectivity and sensitivity. The introduction of metal nanoparticles such asCuNPs, PtNPs, and both metal nanoparticles into the hybrid material was proven to be useful for increasing the detection range.

All methods described in this paper can be applied in the detection of uric acid in human fluids in a combined range between $0.582 \times 10^{-6}-1.5763 \times 10^{-5} \mathrm{M}$ UA concentrations (Figure 24), the lowest detection being realized by TAmPP alone with a detection limit of $0.28 \mu \mathrm{M}$ UA. The materials were characterized by morphological studies before and after treatment with UA. One of the largest domain for UA detection was obtained by the TAmPP-CuNPs hybrid, that was able to detect and quantify the largest concentration domain $5.03 \times 10^{-6}-1.40 \times 10^{-5} \mathrm{M} \mathrm{UA}$, but with main drawback of $\mathrm{CH}_{3} \mathrm{COONa}$ and sodium salicylate which may be problematic interferences if present in 1000 fold higher concentrations than UA. Besides, this domain is partially covered by TAmPP-Pt@CuNPs and partially by TAmPP-PtNPs, as clearly presented in Figure 24 .

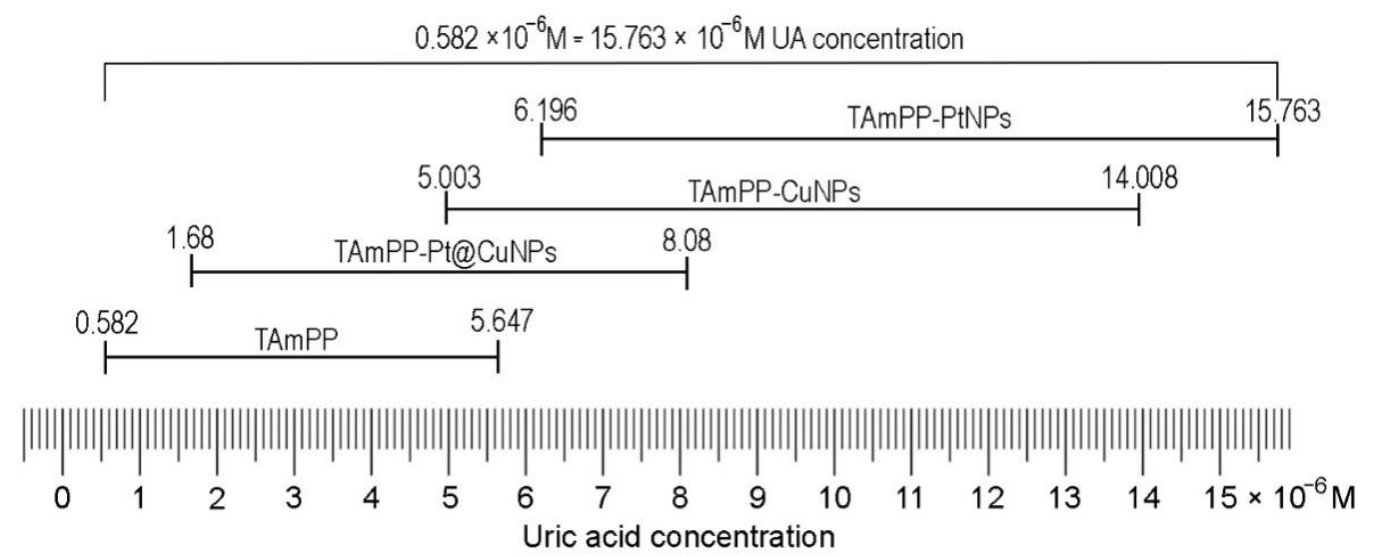

Figure 24. The field of UA detection covered by the materials containing TAmPP used in this study.

The hybrid TAmPP-PtNPs show a more wide, stable, and selective response for UA detection (domain range $6.19 \times 10^{-6}-15.76 \times 10^{-6} \mathrm{M}$ ) not being disturbed by in the presence of interference species present in human environment even if in very high concentrations.

The use of the hybrid TAmPP-Pt@CuNPs has the advantage of lowering the detection to trace detection of uric acid $1.68 \times 10^{-6}-8.08 \times 10^{-6} \mathrm{M}$ when linear dependence is calculated considering the absorption intensity on Soret band, and $1.13 \times 10^{-6}-5.48 \times 10^{-6} \mathrm{M}$ if using the intensity values measured on QI band. Another economically important aspect is the use of a smaller amount of platinum.

The realized complementarity between the detection domains, as presented in Figure 24, is making this method a useful one for uric acid quantification from all types of biological fluid samples.

Supplementary Materials: The following are available online at https:/ / www.mdpi.com/article/ 10.3390/pr9112072/s1. 2.9. Obtaining of hybrid complex between CuNPs and TAmPP porphyrin with UV-Vis, fluorescence and FT-IR spectra of TAmPP, CuTAmPP and CuNPs-TAmPP (Figures S1-S3); 3.2. Detection of UA using TAmPP-CuNPs (Figures S4 and S5) with Interference study (Figures S6 and S7).

Author Contributions: C.E. and I.F. contributed equally to this work. Conceptualization, E.F.-C.; methodology, E.F.-C.; software, I.F.; validation, E.F.-C. and M.B.; formal analysis, M.B., C.O., C.E., I.F. and D.A.; investigation, M.B., C.O., C.E., I.F. and D.A.; resources, E.F.-C.; data curation, C.O., C.E. and I.F.; writing-original draft preparation, M.B., C.O., C.E. and I.F.; writing—review and editing, E.F.-C.; visualization, E.F.-C.; supervision, E.F.-C.; project administration, E.F.-C.; funding acquisition, E.F.-C. All authors have read and agreed to the published version of the manuscript. 
Funding: This research was funded by UEFISCDI, grant number 76 PCCDI/2018-ECOTECH-GMP, Project belonging to PNIII-Future and Emerging Technologies and partially by Romanian Academy through Programme 3/2021 from Institute of Chemistry "Coriolan Dragulescu".

Institutional Review Board Statement: Not applicable.

Informed Consent Statement: Not applicable.

Data Availability Statement: Not applicable.

Conflicts of Interest: The all authors declare that the research was conducted in the absence of any commercial or financial relationships that could be construed as a potential conflict of interest.

\section{References}

1. Ramesh, P.; Sampath, S. Selective Determination of Uric Acid in Presence of Ascorbic Acid and Dopamine at Neutral pH Using Exfoliated Graphite Electrodes. Electroanalysis 2004, 16, 866-869. [CrossRef]

2. Zhang, F.; Ma, P.; Deng, X.; Sun, Y.; Wang, X.; Song, D. Enzymatic determination of uric acid using water-soluble CuInS/ZnS quantum dots as a fluorescent probe. Microchim. Acta 2018, 185, 499. [CrossRef] [PubMed]

3. Qu, S.; Li, Z.; Jia, Q. Detection of Purine Metabolite Uric Acid with Picolinic-Acid-Functionalized Metal-Organic Frameworks. ACS Appl. Mater. Interfaces 2019, 11, 34196-34202. [CrossRef] [PubMed]

4. Wang, C.; Yuan, R.; Chai, Y.; Zhang, Y.; Hu, F.; Zhang, M. Au-nanoclusters incorporated 3-amino-5-mercapto-1,2,4-triazole film modified electrode for the simultaneous determination of ascorbic acid, dopamine, uric acid and nitrite. Biosens. Bioelectron 2011, 30, 315-319. [CrossRef]

5. Income, K.; Ratnarathorn, N.; Khamchaiyo, N.; Srisuvo, C.; Ruckthong, L.; Dungchai, W. Disposable Nonenzymatic Uric Acid and Creatinine Sensors Using $\mu$ PAD Coupled with Screen-Printed Reduced Graphene Oxide-Gold Nanocomposites. Int. J. Anal. Chem. 2019, 2019, 3457247. [CrossRef]

6. Abellán-Llobregat, A.; Vidal, L.; Rodríguez-Amaro, R.; Berenguer-Murcia, Á.; Canals, A.; Morallón, E. Au-IDA microelectrodes modified with Au-doped graphene oxide for the simultaneous determination of uric acid and ascorbic acid in urine samples. Electrochim. Acta 2017, 227, 275-284. [CrossRef]

7. Leko, M.B.; Gunjača, I.; Pleić, N.; Zemunik, T. Environmental Factors Affecting Thyroid-Stimulating Hormone and Thyroid Hormone Levels. Int. J. Mol. Sci. 2021, 22, 6521. [CrossRef]

8. Sundar, S.; Kwon, S.J.; Venkatachalam, G. Magneto-Biosensor for the Detection of Uric Acid Using Citric Acid-Capped Iron Oxide Nanoparticles. J. Nanosci. Nanotechnol. 2020, 20, 2144-2153. [CrossRef]

9. Huang, L.; Jiao, S.; Li, M. Determination of uric acid in human urine by eliminating ascorbic acid interference on copper(II)polydopamine immobilized electrode surface. Electrochim. Acta 2014, 121, 233-239. [CrossRef]

10. Flowers, P.A.; Dong, X.; Bounds, J.G. Kinetic Spectroelectrochemical Assay for Uric Acid in Human Urine. Electroanalysis 2020, 33, 75-80. [CrossRef]

11. Hernández, S.; Perales-Rondon, J.V.; Heras, A.; Colina, A. Determination of uric acid in synthetic urine by using electrochemical surface oxidation enhanced Raman scattering. Anal. Chim. Acta 2019, 1085, 61-67. [CrossRef]

12. Amjadi, M.; Manzoori, J.L.; Hallaj, T. Chemiluminescence of graphene quantum dots and its application to the determination of uric acid. J. Lumin. 2014, 153, 73-78. [CrossRef]

13. Zuo, Y.; Wang, C.; Zhou, J.; Sachdeva, A.; Ruelos, V.C. Simultaneous Determination of Creatinine and Uric Acid in Human Urine by High-Performance Liquid Chromatography. Anal. Sci. 2008, 24, 1589-1592. [CrossRef]

14. Gupta, R.; Ganesan, V. Gold nanoparticles impregnated mesoporous silica spheres for simultaneous and selective determination of uric acid and ascorbic acid. Sens. Actuators B Chem. 2015, 219, 139-145. [CrossRef]

15. Xu, P.; Li, R.; Tu, Y.; Yan, J. A gold nanocluster-based sensor for sensitive uric acid detection. Talanta 2015, 144, 704-709. [CrossRef] [PubMed]

16. Liu, Y.; Li, H.; Guo, B.; Wei, L.; Chen, B.; Zhang, Y. Gold nanoclusters as switch-off fluorescent probe for detection of uric acid based on the inner filter effect of hydrogen peroxide-mediated enlargement of gold nanoparticles. Biosens. Bioelectron. 2017, 91, 734-740. [CrossRef]

17. Norazmi, N.; Rasad, Z.R.A.; Mohamad, M.; Manap, H. Uric acid detection using uv-vis spectrometer. In Proceedings of the 4th International Conference on Mechanical Engineering Research, Kuantan, Malaysia, 1-2 August 2017; p. 012031.

18. Gao, J.; Huang, W.; Chen, Z.; Yi, C.; Jiang, L. Simultaneous detection of glucose, uric acid and cholesterol using flexible microneedle electrode array-based biosensor and multi-channel portable electrochemical analyzer. Sens. Actuators B Chem. 2019, 287, 102-110. [CrossRef]

19. Wang, X.; Chen, S.; Tang, X.; Lin, D.; Qiu, P. Ultrasensitive detection of uric acid in serum of patients with gout by a new assay based on Pt@Agnanoflowers. RSC Adv. 2019, 9, 36578-36585. [CrossRef]

20. Norvaiša, K.; Kielmann, M.; Senge, M.O. Porphyrins as Colorimetric and Photometric Biosensors in Modern Bioanalytical Systems. ChemBioChem 2020, 21, 1793-1807. [CrossRef] [PubMed]

21. Yang, Y.; Sun, R.; Li, M.; Geng, B.; Deng, J.; Tang, M. Porphyrin Functionalized Graphene for Sensitive Electrochemical Detection of Uric Acid. Int. J. Electrochem. Sci. 2016, 11, 7370-7379. [CrossRef] 
22. Guo, X.; Guo, B.; Li, C.; Wang, Y. Amperometric Highly Sensitive Uric Acid sensor Based on Manganese(III)porphyrin-Graphene Modified Glassy Carbon Electrode. J. Electroanal. Chem. 2016, 783, 8-14. [CrossRef]

23. Wang, C.; Yuan, R.; Chai, Y.; Chen, S.; Zhang, Y.; Hu, F.; Zhang, M. Non-covalent iron(III)-porphyrin functionalized multi-walled carbon nanotubes for the simultaneous determination of ascorbic acid, dopamine, uric acid and nitrite. Electrochim. Acta 2012, 62, 109-115. [CrossRef]

24. Deng, K.; Zhou, J.; Li, X. Noncovalent nanohybrid of cobalt tetraphenylporphyrin with graphene for simultaneous detection of ascorbic acid, dopamine, and uric acid. Electrochim. Acta 2013, 114, 341-346. [CrossRef]

25. Chen, $\mathrm{Z}$; $\mathrm{Zu}, \mathrm{Y}$. Selective detection of uric acid in the presence of ascorbic acid based on electrochemiluminescence quenching. J. Electroanal. Chem. 2008, 612, 151-155. [CrossRef]

26. Pang, S. A ratiometric fluorescent probe for detection of uric acid based on the gold nanoclusters-quantum dots nanohybrid. Spectrochim. Acta Part A Mol. Biomol. Spectrosc. 2019, 222, 117233. [CrossRef]

27. Desmoni, E.; Brunetti, B. About Estimating the Limit of Detection by the Signal to Noise Approach. Pharm. Anal. Acta 2015, 6, 1000355. [CrossRef]

28. Araghi, M.; Mirkhani, V.; Moghadam, M.; Tangestaninejad, S.; Mohammdpoor-Baltork, I. Synthesis and characterization of a new porphyrin-polyoxometalate hybrid material and investigation of its catalytic activity. Dalton Trans. 2012, 41, 3087-3094. [CrossRef]

29. Pham, N.-D.; Duong, M.-M.; Le, M.-V.; Hoang, H.A.; Pham, L.-K.-O. Preparation and characterization of antifungal colloidal copper nanoparticles and their antifungal activity against Fusariumoxysporum and Phytophthoracapsici. ComptesRendusChim 2019, 22, 786-793. [CrossRef]

30. Aguilar-Ortiz, E.; Jalilian, A.R.; Avila-Rodriguez, M.A. Synthesis, characterization and evaluation of a Cu-labeled macrocyclicporphyrin as a potential chelator for 64Cu-based radiopharmaceuticals. J. Radioanal. Nucl. Chem. 2019, 320, 79-86. [CrossRef]

31. He, T.; Wang, W.; Shi, F.; Yang, X.; Li, X.; Wu, J.; Yin, Y.; Jin, M. Mastering the surface strain of platinum catalysts for efficient electrocatalysis. Nature 2021, 598, 76-81. [CrossRef]

32. Bu, L.; Zhang, N.; Guo, S.; Zhang, X.; Li, J.; Yao, J.; Wu, T.; Lu, G.; Ma, J.-Y.; Su, D.; et al. Biaxially strained PtPb/Pt core/shell nanoplate boosts oxygen reduction catalysis. Science 2016, 354, 1410-1414. [CrossRef] [PubMed]

33. Schilling, M.; Brimaud, S.; Behm, R.J. Electronic effects on the water adsorption behaviour and structure formation on pseudomorphic Pt films on Ru(0001). Surf. Sci. 2018, 676, 30-38. [CrossRef]

34. Woźniak-Budych, M.J.; Langer, K.; Peplińska, B.; Przysiecka, Ł.; Jarek, M.; Jarzębski, M.; Jurga, S. Copper-gold nanoparticles: Fabrication, characteristic and application as drug carriers. Mater. Chem. Phys. 2016, 179, 242-253. [CrossRef]

35. Tangeysh, B.; Tibbetts, K.M.; Odhner, J.H.; Wayland, B.B.; Levis, R.J. Triangular Gold Nanoplate Growth by Oriented Attachment of Au Seeds Generated by Strong Field Laser Reduction. Nano Lett. 2015, 15, 3377-3382. [CrossRef]

36. Wang, J.; Guo, X.; He, Y.; Jiang, M.; Sun, R. The synthesis and tribological characteristics of triangular copper nanoplates as a grease additive. RSC Adv. 2017, 7, 40249-40254. [CrossRef]

37. Botasini, S.; Dalchiele, E.A.; Benech, J.C.; Méndez, E. Stabilization of triangular and heart-shaped plane silver nanoparticles using 2-thiobarbituric acid. J. Nanopart. Res. 2011, 13, 2819-2828. [CrossRef]

38. Wu, G.-W.; He, S.-B.; Peng, H.-P.; Deng, H.-H.; Liu, A.-L.; Lin, X.-H.; Xia, X.-H.; Chen, W. Citrate-Capped Platinum Nanoparticle as a Smart Probe for Ultrasensitive Mercury Sensing. Anal. Chem. 2014, 86, 10955-10960. [CrossRef]

39. Ghosh, T.; Gerbig, L.; Lambov, M.; Dechant, M.; Lehmann, M. Liquid crystals from shape-persistent porphyrin stars with intrinsic free space. J. Mater. Chem. C 2020, 8, 5562-5571. [CrossRef] 